\title{
TRENDS IN FREE TRADE: LEGAL AND POLICY PERSPECTIVES ON JORDAN'S REGIONAL TRADE ARRANGEMENTS
}

\author{
Mohammad F.A. Nsour, Abdullah Dmour* and Lana Nimri** \\ INTRODUCTION
}

Since the establishment of the World Trade Organization (WTO) in 1995, the number of Regional Trade Arrangements (RTAs) has grown dramatically. ${ }^{1}$ At present, more than half of the world's trade takes place within RTAs. ${ }^{2}$ According to the WTO, as of July 31, 2013, the GATT/WTO had received some 575 notifications of RTAs (counting goods and services separately), ${ }^{3}$ as compared with forty such notifications in $1990 .^{4}$ Corresponding to this increase in volume, the coverage of RTAs has also expanded over time to include services, trade and investment, competition, government procurement, electronic commerce, and labor and environmental standards, in addition to preferential liberalization of tariffs and other measures governing merchandise trade. ${ }^{5}$

This "new regionalism," which increasingly involves webs of agreements covering a range of issues at varying depths, is the reality of the international trading system today. Excluding Mongolia, every WTO Member is party to one or more RTAs. ${ }^{6}$ As such, most developing countries of Law.

* Practicing lawyers and assistant law professors at the University of Jordan Faculty

** Lawyer and Legal Advisor at the Jordan Enterprise Development Corporation. This research was conducted under the support of the WTO-Chair Programme at the University of Jordan. The authors acknowledge with appreciation the support and encouragement they received from the WTO Chair at the University of Jordan, Professor Talib Awad Warrad.

1. The term "Regional Trade Arrangements," as used here refers to free trade agreements, customs unions, or common markets consisting of two or more countries or partners. DiCTIONARY OF TRADE POLICY TERMS (5th ed. 2007), archived at http://perma.cc/6Y85-FRT2.

2. Jo-Ann Crawford \& Roberto V. Fiorentino, The Changing Landscape of REgional Trade AgreEments 1-2, http://www.wto.org/english/res_e/booksp_e/ discussion_papers8_e.pdf, archived at http://perma.cc/7B3R-59YV (the authors use the term Preferential Trade Agreements while this Article uses the synonymous Regional Trade Agreements); see also World Trade Org., World Trade Report 2011, WTO AND Preferential Trade Agreements: From Co-Existence to Coherence, 67, archived at http://perma.cc/XR44-J22M [hereinafter REPORT 2011].

3. Regional Trade Agreements, WORLD TRADE ORG., http://www.wto.org/english/ tratop_e/region_e/region_e.htm (last visited Sept. 22, 2013, archived at http://perma.cc/FUZ2-RBLX).

4. Jo-Ann Crawford \& Sam Laird, Regional Trade Agreements and the WTO, $12 \mathrm{~N}$. AM. J. ECON. FIN. 193, 194 (2001).

5. REPORT 2011, supra note 2.

6. See Participation in Regional Trade Agreements, World Trade Org., 
are actively pursuing regionalism as a route to integrate their economies into the global system and promote sustainable economic development. ${ }^{7}$ Jordan is no exception.

Jordan has followed a liberalization policy in an attempt to increase foreign investment and create more job opportunities. ${ }^{8}$ Currently, Jordan is ranked as one of the most open economies in the world. ${ }^{9}$ Jordan acceded to the WTO in 2000 and became party to trade liberalization arrangements with various countries, including the United States, the European Union, and, most recently, Canada. ${ }^{10}$

This Article is both part of and funded by the WTO Chair Program at the University of Jordan. It presents an overview of the legal and factual status quo of Jordan's regional trade arrangements, touching upon their development and coverage, as well as surveying/examining Jordan's existing foreign trade policy. This Article is not meant to be an extensive analysis of Jordan's free trade arrangements; rather, it is designed to tackle legal and policy concerns regarding some essential aspects of Jordan's regional trade policies. While the Article does not analyze the economic consequences of these RTAs, it does use several points of economic data in the arguments presented herein.

Part I defines the WTO's legal framework with respect to regional and preferential trade and also outlines the theoretical foundation of regional and preferential trade. Part II sheds light on Jordan's trade policy and underlines historical milestones achieved during its progression. Part III is connected with Part II and it considers Jordan's regional and preferential trade agreements in order to pave the road for the discussion in the ensuing parts. Part IV proceeds to define each trade agreement to which Jordan is a party and offers certain remarks on each of these agreements. Finally, Part

http://www.wto.org/english/tratop_e/region_e/rta_participation_map_e.htm (last visited Aug. 15, 2014, archived at http://perma.cc/FHA5-QQZY); see also Welcome to the Regional Trade Agreements Information System (RTA-IS), WORLD TRADE ORG., http://rtais.wto.org/UI/PublicSearchByMemberResult.aspx?MemberCode=496\&lang=1\&red irect=1 (last updated Aug. 14, 2014, archived at PERMA).

7. See Participation in Regional Trade Agreement, supra note 6.

8. See Jordan Foreign Trade Policy, Ministry of Industry And Trade: The HASHEMITE KINGDOM OF JORDAN, http://www.mit.gov.jo/tabid/475/Jordan\%20Foreign \%20Trade\%20Policy.aspx (last visited Aug. 15, 2014, archived at http://perma.cc/WW8GSTMY). 1 (2007), available at http://www.luc.edu/orgs/meea/volume9/PDFS/Squalli\%20 Wilson\%20-\%20paper.pdf.

9. See generally Jay Squalli \& Kenneth Wilson, How Open Are Arab Economies? An Examination with the CTI Measure, 9 TOPICS IN MidDle EASTERn AND NORTH AFriCAN ECONOMIES, Middle East Economic Association and Loyola University Chicago, September, 2007, http://www.luc.edu/orgs/meea/.

10. Jordan Foreign Trade Policy, supra note 8; Agreement Between Canada and the Hashemite Kingdom of Jordan for the Promotion and Protection of Investments, Canada Treaty Information, http://www.treaty-accord.gc.ca/text-texte.aspx?id=105176 (last visited Apr. 23, 2014, archived at http://perma.cc/SA2K-JJYT). 
$\mathrm{V}$ reflects upon Jordan's trade policy and agreements and provides observations thereon. This Article concludes that Jordan's agreements were largely politically driven, and that in the course of crafting its trade agreements, Jordan often gave up some of the flexibility that it would have been afforded under the multilateral trading system. Accordingly, after more than a decade of active regionalization, Jordan's trade and economic balances remain, unsurprisingly, negative.

\section{THE WTO LEGAL FRAMEWORK}

Provided certain conditions are met, WTO Members are allowed to enter into preferential arrangements that depart from the most-favorednation (MFN) treatment. ${ }^{11}$ In the 1940s, the original General Agreement on Tariffs and Trade (GATT) rules for RTAs were introduced. ${ }^{12}$ At that time, little attention was given to non-tariff measures and, more importantly, it was not expected that the exception embodied in GATT Article XXIV would be heavily invoked. ${ }^{13}$ That understanding was valid, since the number of existing RTAs at that time was insignificant. ${ }^{14}$ Though the creation of GATT in 1948 did not rescind previous bilateral agreements, it did introduce a new reality: agreements had to be brought into accordance with the rules of the GATT or any exceptions thereunder. This grandfathering process materialized most notably in preferential treatment between trading partners; accordingly, many colonial powers, including the United States, the United Kingdom, Belgium, and the Netherlands, maintained their preferential trade agreements with their respective colonies. $^{15}$

The RTA tsunami occurred in the 1990s, particularly after the collapse of the Berlin Wall and the creation of the WTO in $1995 .{ }^{16}$ Not only did the number of RTAs skyrocket, ${ }^{17}$ but the coverage of RTAs also became more extensive, expanding to include non-tariff barriers with respect to

11. See General Agreement on Tariffs and Trade art. XXIV, Oct. 30, 1947, 61 Stat. A11, 55 U.N.T.S. 194 [hereinafter GATT]; see also General Agreement on Trade in Services, Dec. 15, 1993, 33 I.L.M. 1167 [hereinafter GATS].

12. See GATT, supra.

13. See South Centre, Article XXIV and RTAs: How Much Wiggle Room for Developing Countries? 4 (2008).

14. See generally Andrew Stoler, The WTO Dispute Settlement Process: Did We Get What the Negotiators Wanted?, 3 WorLd TRADE REV. 99 (2004).

15. Joanne Gowa \& Soo Yeon Kim, An Exclusive Country Club: The Effects of the GATT on Trade, 1950-94, 57 WORLD POL. 453, 459 (2006), archived at http://perma.cc/LUZ2-NHZE.

16. Marc Bungenberg \& Christoph Herrmann, Common Commercial Policy after Lisbon, Eur. Y.B. of Int'1 Econ. Law 3-4 (2013).

17. Regional Trade Agreements, supra note 3. 
trade-in goods, ${ }^{18}$ as well as services, intellectual property, and investment. ${ }^{19}$ These agreements have also substantively expanded to encompass items on competition policy, government procurement, labor and environmental standards, electronic commerce, and human rights. ${ }^{20}$

The essence of the rules of the global trading system reflects the principles of non-discrimination. The preamble of the Marrakesh Agreement Establishing the World Trade Organization clearly states that one of the main objectives of the Organization is to promote "entering into reciprocal and mutually advantageous arrangements directed to the substantial reduction of tariffs and other barriers to trade and to the elimination of discriminatory treatment in international trade relations."21 The principles of non-discrimination are substantive legal obligations placed on all WTO Members and are reflected in numerous provisions of the WTO Agreement.

In WTO law, there are two main concepts of non-discrimination: 1) the most-favored-nation treatment obligation (MFN); and 2) the national treatment obligation (NT). ${ }^{22}$ In the General Agreement on Tariffs and Trade (GATT), the principle of MFN is set out in article I and also appears in various forms in articles II.1, V.5, IX.1, and XIII.1, while the principle of NT appears in article III. ${ }^{23}$ In the General Agreement on Trade in Services (GATS), article II sets out the principle of MFN and article XVII sets out that of NT. ${ }^{24}$ In the Agreement on Trade-Related Aspects of Intellectual Property Rights (TRIPS), the principles of MFN and NT are found in articles 3 and 4, respectively. ${ }^{25}$ These two key principles are also found in

18. See generally Natalie Shimmel, Welcome to Europe, but Please Stay Out: Freedom of Movement and the May 2004 Expansion of the European Union, 24 BERKELEY J. INT'L L. 760 (2006) (outlining different aspects and consequences of the EU 2004 expansion).

19. See e.g., Foreign Investment Promotion and Protection (FIPAs), FOREIGN AfFAIRS, TRADE AND DEV. CANADA, http://www.international.gc.ca/trade-agreements-accordscommerciaux/agr-acc/fipa-apie/index.aspx?lang=eng (last updated Dec. 18, 2013, archived at http://perma.cc/J72K-V73V).

20. Crawford \& Fiorentino, supra note 2, at 1.

21. Marrakesh Agreement Establishing the World Trade Organization pmbl., Apr. 15, 1994, 1867 U.N.T.S. 154 [hereinafter Marrakesh Agreement], archived at http://perma.cc/CK37-G498. Under the Uruguay Round package 1992-1993, negotiations finally produced agreement on text of the TRIPS, thereby extending the multilateral trading system to cover intellectual property (IPs). Agreement on Trade-Related Aspects of Intellectual Property Rights, Apr. 15, 1994. See id. Annex 1C.

22. Principles of the Trading System, WorLd TRADE OrG., http://www.wto.org/english/thewto_e/whatis_e/tif_e/fact2_e.htm (last visited Aug. 16, 2014, archived at $\mathrm{http}: / /$ perma.cc/CZ97-5NQL).

23. GATT, supra note 11.

24. GATS, supra note 11, art. 2.

25. Marrakesh Agreement, supra note 21, Annex 1C. 
other WTO agreements. ${ }^{26}$ However, WTO Members are permitted to depart from the non-discrimination rules under specific conditions, which vary depending on the level of integration sought, mainly according to article XXIV of the GATT, article V of the GATS for MFN and the Tokyo Round's Decision on Differential and More Favorable Treatment, Reciprocity, and Fuller Participation of Developing Countries (the Enabling Clause). ${ }^{27}$

It was initially hoped that GATT Article XXIV would be the system's instrument for "both managing RTAs and encouraging their transformation into multilateral GATT trade agreements" 28 and that was applicable also to Article V of the GATS. However, many view RTAs' proliferation, which has resulted in RTAs constituting an essential portion of the world trade, as a threat to the multilateral system itself. ${ }^{29}$

RTAs are recognized as reciprocal trade agreements between two or more partners and include FTAs, CUs, and common markets. ${ }^{30}$ PTAs in the WTO "are unilateral trade preferences," that include the Generalized System of Preferences (GSP) schemes, as well as other non-reciprocal preferential schemes granted a waiver by the WTO General Council ${ }^{31}$ pursuant to Article IX (Decision Making) of the WTO Agreement. ${ }^{32}$

26. See e.g., GATT, supra note 11 , art. I, I 1 (regarding the principle of nondiscrimination, stating that members "shall unconditionally offer to all other contracting parties (members) any advantage, favour, privilege or immunity affecting customs duties, charges, rules and procedures that they give to products originating in or destined for any other country.").

27. Decision, Differential and More Favourable Treatment, Reciprocity, and Fuller Participation of Developing Countries, 11 (Nov. 28, 1979), GATT B.I.S.D. (26th Supp.) (1980) [hereinafter Enabling Clause].

28. See generally Donald A. Calvert, How the Multilateral Trade System Under the World Trade Organization is Attempting to Reconcile the Contradictions and Hurdles Posed by Regional Trade Agreements: An Analysis of Article XXIV of the General Agreement on Tariffs and Trade 4 (Dec. 6, 2002) (unpublished Master's Capstone Thesis, George Mason University), archived at http://perma.cc/T6G8-TT2W.

29. See Welcome to the Regional Trade Agreements Information System (RTA-IS), supra note 6 . The recent proliferation of RTAs in the form of free trade agreements demonstrates countries' favoritism of these over customs unions. Welcome to the Regional Trade Agreements Information System (RTA-IS), supra note 6. This suggests that if the GATT framers had been aware of the potential use of Article XXIV, they would have included a customs union-only requisite, something that might have deterred many of current RTAs from forming. See Kerry A. Chase, Multilateralism Compromised: The Mysterious Origins of GATT Article XXIV, 5 World TRADE REV. 1 (2006).

30. Regional Trade Agreements and Preferential Trade Agreements, WorLd TRADE ORG., http://www.wto.org/english/tratop_e/region_e/rta_pta_e.htm (last visited Aug. 16, 2014, archived at http://perma.cc/8BXD-7XWR).

31. Id.

32. See Preferential Tariff Treatment for Least Developing Countries, July 17, 1999 (WT/L/304). On June 15, 1999, the WTO General Council adopted a decision (WT/L/304) that grants a General Agreement on Tariffs and Trade (GATT) waiver to the preferential 
Free Trade Agreements (FTAs) are the most popular mode of regionalism. FTAs encompass an arrangement that allows for the unimpeded flow of trade in goods between members at either a very low, or a zero tariff rate, subject to the conditions of the specified rules of origin. ${ }^{33}$ FTAs have proliferated mainly because they offer flexibility to their members. ${ }^{34}$ These agreements do not entail the mandatory adoption of similar trade policies; they simply require economic compatibility and probably political compatibility as well. ${ }^{35}$ While the conventional form of FTAs simply liberalizes trade in goods, these agreements have taken many forms that vary from this basic model, such as FTAs that contain provisions on investment, as in the NAFTA, or FTAs that encompass non-trade issues related to human rights and democracy, as in several EU agreements. ${ }^{36}$

When members of FTAs wish to achieve deeper economic integration, they can adopt common external tariff rates, commonly termed "customs unions." 37 If members of a customs union allow the unimpeded movement of products, capital, and people, then the customs union becomes a common market. ${ }^{38}$ Monetary union is another deeper integration model

tariff treatment by developing countries for exports from the least developed countries. $I d$. The waiver would effectively provide a legal cover to those initiatives pledged and engaged in by several developing countries to facilitate market access for the least developed countries. Id. The waiver authorizes derogation from the most-favored-nation (MFN) principle until June 30, 2009 by developing country WTO members that grant unilateral preferential tariff treatment to products imported from the least developed countries members. See Decision on Waiver, Preferential Tariff Treatment for Least-Developed Countries, WT/L/304 (June 17, 1999) (adopted June 15, 1999); Request for Extension of Waiver, European Communities-Autonomous Preferential Treatment to the Countries of the Western Balkans, G/C/W/552; G/C/W/556 (May 5, 2006). Examples of preferential trade agreement include the Lomé IV Agreement, preferential arrangements for the Caribbean by the United States and Canada, or a recently agreed waiver permitting more advanced developing countries to extend duty-free preferences on a non-reciprocal basis to LDCs.

33. See supra note 32 and accompanying text. I thank the WTO external reviewer who noted that tariff peaks often remain.

34. Mohammad F.A. Nsour, Regional Trade Agreements in the Era of Globalization: A Legal Analysis, 33 N.C. J. INT'L L. \& COM. REG. 359, at 369 (2007) (stating that FTAs are the most popular RTAs).

35. Martin Richardson, Why a Free Trade Area? The Tariff Also Rises, 6 Econ. \& PoL. 79,88 (1994).

36. See Nsour, supra, at 371.

37. Harry Johnson, The Economic Theory of Customs Union, in Trading Blocs: Alternative Approaches to Analyzing Preferential Trade Agreements, 127, 133 (Jaqdish N. Bhaqwati et al., eds., 1999).

38. See e.g., Case C- 221/89, The Queen v. Sec'y of State for Transp. ex parte Factortame Ltd., 1999 E.C.R. 3905, $\mid$ 20. The difference between a Customs Union and a FTA is the authority to change tariffs on imports from non-member countries. Id. Countries within a Customs Union introduce common tariff rates against all non-member countries, and they cannot change tariff rates voluntarily without prior consultation with other member countries. Id. However, countries in a FTA can set their own tariff rates independently; if a country is a WTO Member, then the tariff rates set under the FTA must not be higher than its WTO-bound rates. See e.g., id. (the EU Court of Justice confirmed this in Factortame II with 
which entails that common markets fix exchange rates and agree on common monetary policies. ${ }^{39}$ Of course, deeper models of integration require higher cooperation, the European Union, arguably, being the best example of such a model.

In the Tokyo Round in 1979, GATT members agreed on a legal framework for preferential trade concerning developing countries. ${ }^{40}$ Under the Enabling Clause, ${ }^{41}$ developing countries can exchange virtually any trade preference. ${ }^{42}$ The Generalized System for Tariff Preferences among Developing Countries (GSTP) ${ }^{43}$ enables developed countries to give developing countries one-way trade preferences. ${ }^{44}$ For example, under the CARIBCAN agreement, Canada accords duty-free non-reciprocal access to most Caribbean countries. ${ }^{45}$ By the same token, the Enabling Clause permits developing countries to exchange trade preference without offering the same preference to developed countries. ${ }^{46}$ Hence, Jordan receives trade preferences under the GSP from Belarus, Canada, the EU, Japan, New Zealand, the Russian Federation, Switzerland, Turkey, and the United States. ${ }^{47}$

In 1996, the WTO created the Committee on Regional Trade

regard to the freedom of establishment by emphasizing that "the concept of establishment within the meaning of Article 52 et seq. of the Treaty involves the actual pursuit of an economic activity through a fixed establishment in another Member State for an indefinite period.").

39. See Joshua M. Wepman, Note, Article 104(c) of the Maastricht Treaty and European Monetary Union: Does Ireland Hold the Key to Success?, 19 B.C. INT'L \& ComP. L. REV. 247 (1996) (defining Monetary Unions).

40. Enabling Clause, supra note 27.

41. See Enabling Clause, supra note 27.

42. Robert Howse, India's WTO Challenge to Drug Enforcement Conditions in the European Community Generalized System of Preferences: A Little Known Case with Major Repercussions for "Political" Conditionality in US Trade Policy, 4 CHI. J. INT'L L. 385, 387 (2003); see also Enabling Clause, supra note 27, art. 2c (allowing developing countries to agree on reciprocal agreements among themselves, without giving the same preferences to developed countries).

43. See generally Howse, supra.

44. Footnote 3 of the Enabling Clause refers to the GSP system initiated at UNCTAD II. The UNCTAD II participants adopted Resolution 21(II), recognizing "unanimous agreement in favour of the early establishment of a mutually acceptable system of generalized, nonreciprocal and non-discriminatory preferences which would be beneficial to the developing countries." See Report of the United Nations Conference on Trade and Development on Its Second Session, UNCTAD, 2d Sess. Annex 1, Agenda Item 11, U.N. TDBOR, , U.N. Doc. TD/97/Annexes (1968) at 38.

45. Caribcan, Belize Trade \& Investment Zone, http://www.belize.org/tiz/caribcan (last visited Aug. 16, 2014, archived at http://perma.cc/5L2N-UM2Q) (“Approximately 98\% of total CARICOM merchandise exports currently enter Canada duty free under MFN, CARIBCAN (CCT) or General Preferential Tariff (GPT).”).

46. See Enabling Clause, supra note 27, art. 5.

47. Un Conference on Trade and DeV., Generalized System of Preferences: List OF BENEFICIARIES 11, archived at http://perma.cc/8VP7-3UKE. 
Agreements (CRTA) to oversee all RTAs and to consider the implications of such agreements on the multilateral trading system. ${ }^{48}$ However, the CRTA proved unable to effectively carry out its duties of examining the consistency of RTAs with RTA rules and overseeing their implementation. ${ }^{49}$ In this light, WTO Members agreed in July 2006 on a new mechanism for transparency that drew specific guidelines for reporting RTAs and outlined clear timetables for that purpose. ${ }^{50}$ This Transparency Mechanism enables the WTO Secretariat to assume the guiding role in addressing the factual aspects of the notified agreements. ${ }^{51}$

\section{OVERVIEW OF JORDAN'S FOREIGN TRADE POLICY}

Jordan's preferential trade initiatives began to evolve in the late 1950s. In 1962, Jordan entered into an economic cooperation agreement with Saudi Arabia to exempt specific products from duties according to each country's ability. ${ }^{52}$ Jordan also signed agreements with India in 1964, Iraq in 1967, and a cooperation agreement with the European Communities that entered into force in $1977 .{ }^{53}$ The latter specifically allowed Jordan to export some agricultural products with reduced tariffs. ${ }^{54}$ The foregoing agreements were all exclusive to goods. ${ }^{55}$ Other regional agreements took place under the Umbrella of the Council of Arab Economic Unity, but with limited success. ${ }^{56}$

In the early 1970s, Jordan strengthened its Import Substitution Industrialization Strategy, originally implemented in the mid-1950s, which aimed at diversifying the industrial base of the economy. ${ }^{57}$ Hence, Jordan

48. World Trade Org., Committee on Regional Trade Agreements Decision of February 1996, WTO Doc WT/L/127 (Feb. 7, 1996).

49. See World Bank, Global Economic Prospects 2005: Trade, Regionalism and DEVELOPMENT 141 (2004).

50. See Decision-Transparency Mechanism for Regional Trade Agreements, WT/L/671 (June 29, 2006).

51. See Transparency Mechanism for Regional Trade Agreements - Final Decision, WTO, WT/L/671 (Dec. 18, 2006).

52. Economic Agreement Between the Hashemite Kingdom of Jordan and Saudi Arabia, Jordan-Saudi Arabia, Oct. 30, 1962, archived at http://perma.cc/9UXJ-PV9C.

53. Press Release, European Union, The EU and Jordan: Long-Standing Relationship (Feb. 21, 2012), archived at http://perma.cc/K5LL-SF7A.

54. Working Party on the Accession of Jordan, Report of the Working Party on the Accession of the Hashemite Kingdom of Jordan to the World Trade Organization, WT/ACC/JOR/33 (Dec. 3, 1999).

55. See Elaine Denney et al., International Economic Development Program, SUSTAINABLE WATER STANDARDS FOR JORDAN (2008), archived at http://perma.cc/KTP5MAFE.

56. See generally YeArbook of InTERnAtional Organizations (33d ed. 1996).

57. Jane Harrigan et al., The IMF and the World Bank in Jordan: A Case of Over Optimism and Elusive Growth, 1 REV. INT. ORG. 263, 265 (2006). 
introduced several tariff and non-tariff barriers including financial subsidies to local producers, particularly the smaller ones. ${ }^{58}$ However, due to the expansionary policies and the nearly unlimited external borrowing the government followed at the time, the total public debt had grown significantly and the government became unable to respond to its debt obligations. ${ }^{59}$

To deal with the struggling economy, Jordan had to defer to the IMF and the World Bank, which required Jordan to adopt comprehensive measures, including reducing import restrictions and eliminating domestic subsidies. ${ }^{60}$ By 1999 , the import weighted average tariff rate had declined to 25 percent, down from 35 percent in $1987 .{ }^{61}$ The maximum tariff rate was also reduced from 70 percent in 1993 to 35 percent in 1999, to reach on average 8.98 percent by $2010 .^{62}$ In 2000 , the Government announced that it accelerated economic "reforms" through further privatization and trade liberalization measures including the introduction of a 10 percent sales tax for the first time. ${ }^{63}$ The sales tax rate increased to 16 percent in 2004, and the weighted average tariff rate fell from 35 percent in 1987 to 13.5 percent in 2000, with the maximum tariff rate declining to 30 percent. $^{64}$

By the end of 2000, Jordan had joined the WTO in record time, and by 2001, Jordan had signed a Free Trade Agreement (FTA) with the United States, after signing an Association Agreement with the European Community in $1997 .{ }^{65}$ Regionally, Jordan was a member of various agreements that promoted economic cooperation between Arab states, such as the Agreement for Facilitating and Developing Trade Exchange among Arab States, which was later replaced with the Greater Arab Free Trade Agreement (GAFTA). ${ }^{66}$

In several areas, Jordan introduced legislation that was compatible with its liberalization policy, including, inter alia, legislation addressing

58. Trade Policy Review: Report by Jordan, Trade Policy Review Body, WT/TPR/G/206 (Oct. 6, 2008), archived at http://perma.cc/MJL3-ZAY7.

59. Id.

60. Id.

61. Id.

62. Id.; see also Jordan - Tariff Rate, INDEX Mund, http://www.indexmundi.com/facts/jordan/tariff-rate (last visited Sep. 23, 2013, archived at http://perma.cc/B7GR-ZAQD).

63. See Trade Policy Review: Report by Jordan, Trade Policy Review Body, WT/TPR/G/206 (Oct. 6, 2008), archived at http://perma.cc/MJL3-ZAY7.

64. Harrigan et al., supra note 57.

65. Agreement Between the United States of America and the Hashemite Kingdom of Jordan on the Establishment of a Free Trade Area, Oct. 24, 2000, U.S.-Jordan, 115 Stat. 2875, archived at http://perma.cc/5AKK-3C57. [hereinafter U.S.-Jordan FTA].

66. Basheer Zobi et al., The Intra Arab Trade under the Umbrella of the Greater Arab Free Trade Area in The Arabic Economic Complementary under The Greater Arab FreE Trade Area 2 (Amman, Jordan: Jordan University Press, 2004). 
intellectual property rights, ${ }^{67}$ competition, ${ }^{68}$ and trade remedies, ${ }^{69}$ as well as legislation establishing free and development zones. ${ }^{70}$ Jordan also adopted other policies to facilitate trade and transport. For instance, Jordan Customs adopted the World Customs Organization's (WCO) Framework of Standards to Secure and Facilitate Global Trade through the "Golden List" program, which was established in 2005. In July 2008, Jordan Customs signed a Mutual Recognition Agreement with the United States Customs and Border Protection, which recognized the compatibility of the Golden List program with the U.S. C-TPAT. ${ }^{71}$ Similarly, Jordan has expedited clearance times by using the current ASYCUDA in most of its customs houses. ${ }^{72}$ Jordan also has an MOU with the Common Market for Eastern and Southern Africa (COMESA), as "[a] preliminary step towards full membership ...."73

At the multilateral level, and in line with accession commitments, ${ }^{74}$ Jordan has signed the WTO Information Technology Agreement and is currently in an advanced stage of negotiations for its accession to the Government Procurement Agreement (GPA). ${ }^{75}$ Jordan also supported the unsuccessful Doha Agenda, which aimed to remove export subsidies and allowed developing countries to designate special and sensitive products, in addition to creating a new regime for safeguards to phase out export subsidies by $2015 .^{76}$

67. For a list of these laws, see Jordan (62 Texts), World InTellectual Prop. OrG., http://www.wipo.int/wipolex/en/profile.jsp?code=JO (last updated Mar. 18, 2013, archived at http://perma.cc/B8LZ-MMSK).

68. See Competition Law No. 33/2004.

69. See National Production Protection Law No. 21/2004; see also Laws, MiNISTRY OF Industry AND TRADE: The HASHEMite KINGDOM OF JORDAN, http://www.mit.gov.jo/ Default.aspx?tabid=428 (last visited Aug. 18, 2014, archived at http://perma.cc/JA6BQHWB).

70. See Free and Development Zones Law No. 2/2008, archived at http://perma.cc/E4Q3-K8HM.

71. Id.

72. Dr. Qais G. Noaman, Anthony Purdy, Marwan Gharaibeh, Joint Evaluation MISSION:

ASYCUDA PROGRAMME IN JORDAN 4 (2002), archived at http://perma.cc/9V9R-8VW3.

73. Jordan, COMESA Sign Agreement, COMESA Tradehub, Mar. 21, 2007, http://lasco.comesatradehub.com/NewsDetail.asp?news_id=344 (alteration in original).

74. Information Technology Agreement, WORLD TRADE ORG., http://www.wto.org/ english/tratop_e/inftec_e/inftec_e.htm (last visited Sep. 23, 2013, archived at http://perma.cc/A73W-QLVR).

75. Government Procurement Agreement/WTO, EUROPEAN COMMISSION, http://ec.europa.eu/internal_market/publicprocurement/rules/gpa-wto/index_en.htm (last visited Sep. 23, 2013, archived at http://perma.cc/AA24-CXNL) ("Negotiations with China, Jordan, the Republic of Moldova and Armenia are ongoing.").

76. The Doha Agenda collapsed. See World Trade Talks End in Collapse, BBC NEws, July 29, 2008, http://news.bbc.co.uk/2/hi/business/7531099.stm, archived at http://perma.cc/Y9C3-3V54. 
In 2005, Jordan developed its 10-year National Agenda (2006-2015), a long-term development plan that primarily aims to improve the quality of life for Jordanians through the creation of income-generating opportunities, increased standards of living, and guarantees of social welfare. ${ }^{77}$ These initiatives are to be undertaken over three consecutive phases and developed along three main dimensions: Government and Policies, Basic Rights and Freedoms, Services, Infrastructure, and Economic Sectors. ${ }^{78}$ Under the latter dimension, the Jordanian Ministry of Industry and Trade developed a National Foreign Trade Strategy (2010-2014), which, along with the Industrial Support Programme, was approved by the Council of Ministers in May of $2010 .^{79}$ The National Foreign Trade Strategy aims to increase consistency and harmony with other policies and sectoral strategies, both those in place and under preparation, as well as ensuring that these strategies are in accordance with the goals and objectives of the National Agenda (2006-2015). ${ }^{80}$ These strategies include the Agriculture Strategy, the National Transportation Strategy, the National Tourism Strategy, the Ecommerce Strategy, the strategy of the Ministry of Environment ("approach towards the green economy"), and the National Industrial Policy. ${ }^{81}$

\section{JORDAN'S TRADE LIBERALIZATION ARRANGEMENTS}

Regionally, Jordan has the highest number of free trade and preferential market access agreements when compared to other Arab countries. ${ }^{82}$ The table below lists Jordan's current FTAs:

\begin{tabular}{|l|l|l|} 
Agreement & $\begin{array}{l}\text { Date } \\
\text { of Signature }\end{array}$ & Date of Entry into Force \\
\hline $\begin{array}{l}\text { Greater Arab Free } \\
\begin{array}{l}\text { Trade } \\
\text { Agreement (GAFTA) }\end{array}\end{array}$ & Feb. 29, 1997 & Jan. 1, 1998 \\
\hline
\end{tabular}

77. The Ministry of Government Performance Within the Prime Ministry, JORDAN NATION AGENDA (2006-2015) - THE JORDAN WE STRIVE FOR 7 (2006), archived at http://perma.cc/5MNU-JMJT.

78. Id.

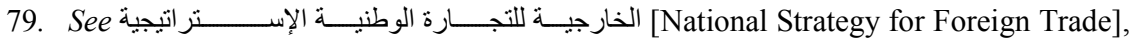
archived at http://perma.cc/B84U-QUXU.

80. According to the authors' conversation with officials at the Ministry of Trade, this work is still in the making.

81. See Dr. Jamal Mahasneh, Jordan's Industrial Policy, Fostering ENTREPRENEURShiP THRough ProActive Policies (2008), archived at http://perma.cc/K7FJM7US.

82. “Jordan, economy of," The New Palgrave Dictionary of Econ., Online Edition (Steven N. Durlauf \& Lawrence E. Blume, eds. 2014), archived at http://perma.cc/HJ8QFT3B.

83. See Greater Arab Free Trade Area (GAFTA), Ministry of Industry \& TRADE, 


\begin{tabular}{|l|l|l|}
$\begin{array}{l}\text { Jordan-EU } \\
\text { Association Agreement }\end{array}$ & $\begin{array}{l}\text { Nov. 24, } \\
1997\end{array}$ & May 1, 2002 \\
\hline $\begin{array}{l}\text { Jordan-US Free Trade } \\
\text { Area Agreement }\end{array}$ & Oct. 24, 2000 & Dec. 17, 2001 \\
\hline $\begin{array}{l}\text { Jordan-EFTA Free } \\
\text { Trade Agreement }\end{array}$ & June 21, 2001 & Jan. 1, 2002 \\
\hline Agadir Agreement & Feb. 25, 2004 & July 6, 2006 \\
\hline $\begin{array}{l}\text { Jordan-Singapore Free } \\
\text { Trade Agreement }\end{array}$ & May 16, 2004 & Aug. 22, 2005 \\
\hline $\begin{array}{l}\text { Jordan-Turkey Free } \\
\text { Trade Agreement }\end{array}$ & Dec. 1, 2009 & Mar. 1, 2011 \\
\hline $\begin{array}{l}\text { Jordan Canada Free } \\
\text { Trade Agreement }\end{array}$ & June 28, 2009 & Oct. 1, 2012 \\
\hline \multicolumn{2}{|l}{} \\
\hline
\end{tabular}

As will be demonstrated below: all these agreements provide for a gradual reduction of import duties on products over a specified period of time. Most of them grant immediate tariff-free access for Jordanian products into the markets of the trading partners. However, Jordan has not yet fully benefited from all these preferential market access opportunities. In fact, there are arguments indicating that trade diversions have taken place. ${ }^{85}$ Jordan's inability to benefit fully from trade has also been facilitated by the fact that Jordan's production capacity of any one product is limited, and by the fact that very little development has actually taken place over the last decade. ${ }^{86}$

The Government of Jordan continues to spearhead plans for further bilateral pacts with Iraq, Kazakhstan, and Pakistan, while also continuing to push for FTAs with MERCOSUR and Russia. ${ }^{87}$ Moreover, in 2010, a Customs Union between Jordan and Egypt was first proposed, with the goal of establishing the Union by $2015 .{ }^{88}$ While technical committees were established and bilateral meetings were held between the two sides, the generally known developments brought about by the Arab Spring rendered

http://www.mit.gov.jo/Default.aspx?tabid=732 (last visited Sep. 23, 2013, archived at http://perma.cc/3A32-W5EG).

84. Welcome to the Regional Trade Agreements Information System (RTA-IS), supra note 6.

85. Jordan Foreign Trade Policy, supra note 8.

86. Jordan's trade deficit is on the rise. See Trade: Jordan trade deficit jumps to 8.6 percent in 2013, ANSA MED, http://www.ansa.it/ansamed/en/news/sections/ economics/2014/01/23/Trade-Jordan-trade-deficit-jumps-8-6-percent-2013_9949393.html (Jan. 23, 2014, archived at http://perma.cc/6EL6-6A32).

87. BilaterAls.ORG, http://www.bilaterals.org/?-Jordan (last visited Sep. 23, 2013, archived at $\mathrm{http}: / /$ perma.cc/MG8G-6F5T).

88. Agreement Free Trade Between the Government of the Hashemite Kingdom of Jordan and the Government of the Arab Republic of Egypt, Oct. 12, 1998, archived at http://perma.cc/76XK-FTS4. 
the prospect of establishing a Customs Union, both bilaterally and at the Arab regional level, stalled indefinitely. During this period, Jordan also took part in another failed attempt at economic integration, for the same latter reasons, together with Turkey, Syria, and Lebanon, in hopes of establishing a regional free trade zone among the countries of the Mashreq. ${ }^{89}$

Following the internal unrest arising from the Arab Spring, Jordan's past efforts to strengthen formal economic relations with the Cooperation Council for the Arab States of the Gulf (GCC) were positively welcomed in early 2011, when Jordan's almost fifteen-year-old request to join the economic bloc was accepted by the six oil-rich Gulf states (Saudi Arabia, Kuwait, Qatar, United Arab Emirates, Oman, and Bahrain). ${ }^{90}$ However, the course changed, and members of the GCC no longer support full Jordanian membership in the GCC. ${ }^{91}$ Instead, the proposal diverted to an aid support initiative - unsurprisingly for the already loose alliance. ${ }^{92}$ But in any event, in the authors' view, Jordan does not need full membership in the GCC. Jordan's core interests at this stage are the following: facilitated access to the GCC labor market, which may be treated within a separate labor movement agreement for skilled and highly skilled workers; ${ }^{93}$ financial and monetary aid packages for alleviating the pressures on the budget deficit;

89. Sandor Richter, Regional Trade Integration in the Middle East and North AFRICA: LESSONS FROM CENTRAL EUROPE (2012), archived at http://perma.cc/87RA-NKJ4.

90. Jordan, Morocco to Join GCC, KHAleEJ Times, May 11, 2011, http://www.khaleejtimes.com/DisplayArticle09.asp?xfile=data/middleeast/2011/May/middle east_May233.xml\&section=middleeast, archived at http://perma.cc/5JKY-ACNC.

91. Johan Weick, GCC States Remain Split Over EU-Styled Union, Feb. 12, 2014, http://gulfbusiness.com/2014/02/gcc-states-remain-split-eu-styled-union/, archived at http://perma.cc/ZGZ7-SVHF.

92. Walid Abdmoulah, Arab Trade Integration: Evidence from Zero-Inflated Negative Binomial Mode, 32 J. OF ECON. COOPERATION AND DEV. 39 (2011), archived at http://perma.cc/LLP6-3XE6. The GCC countries are parties to GAFTA, giving preferential access to Jordanian-originating goods. Id.

93. Labour Markets Integration Agreements provide that the GATS

shall not prevent any of its Members from being a party to an agreement establishing full integration of the labour markets between or among the parties to such an agreement, provided that such an agreement: (a) exempts citizens of parties to the agreement from requirements concerning residency and work permits; [and] (b) is notified to the Council for Trade in Services.

GATS, supra note 11, art. 5 (internal citation omitted) (alteration added). Footnote to the Article further states that "[t]ypically, such integration provides citizens of the parties concerned with a right of free entry to the employment markets of the parties and includes measures concerning conditions of pay, other conditions of employment and social benefits." GATS, supra note 11, art. 5, at n.2 (alteration added). Note also here that the GATS Annex on Movement of Natural Persons Supplying Services under the Agreement clearly provides that the GATS "shall not apply to measures affecting natural persons seeking access to the employment market of a Member, nor shall it apply to measures regarding citizenship, residence or employment on a permanent basis." GATS, supra note 11, at 1189. 
and preferential oil and gas prices. ${ }^{94}$

\section{JORDAN's FREE TRADE AGREEMENTS}

\section{A. Jordan-EU Association Agreement (towards the Euromed Free Trade Area)}

The European Union (EU) is a significant user of FTAs in the framework of region-to-region negotiations. The EU utilizes free trade arrangements in combination with other policies and agreements to promote economic, political and security considerations. ${ }^{95}$ In general, the EU's bilateral and regional arrangements not only cover a range of new issues at deeper depths than traditional FTAs, but they are distinctively European in that they promote the EU model of integration, using legal linkages and tieins to encourage regional integration among and between the partner countries, while simultaneously pushing for harmonization with the acquis communautaire. ${ }^{96}$

The EU's "Southern Mediterranean Region" includes Jordan, Morocco, Algeria, Tunisia, Egypt, Israel, Lebanon, Syria, ${ }^{97}$ the Palestine Authority, and Turkey. ${ }^{98}$ The trade relations between the EU and these countries are managed by the "Euromed Partnership," which was

94. Jordan, GCC Approve Action Plan 2012-2017, Breitbart, Nov. 7, 2012, archived at http://perma.cc/6CFZ-FHU6.

95. See generally Donah Baracol PinhaO, International Institute For Democracy and Electoral Assistance, The ASEAN-EU Free Trade Agreement: IMPLICATIONS FOR DEMOCRACY PROMOTION IN THE ASEAN REgION, archived at http://perma.cc/NMQ3-UM3D.

96. Community Acquis, EuroVoc: Multilingual Thesaurus of the European UNION (last visited Aug. 19, 2014), http://eurovoc.europa.eu/drupal/?q=request\& uri=http://eurovoc.europa.eu/210682, archived at http://perma.cc/72KG-BMC7 (acquis communautaire is the body of EU law contained in all legislation adopted under the treaties establishing the European Union, including regulations, directives, decisions, recommendations and opinions).

97. Syria, Eur. Union: EXternal ACtion (last visited Aug. 19, 2014), http://www.eeas.europa.eu/syria/index_en.htm, archived at http://perma.cc/EE5X-DT8J (with respect to Syria, negotiations of the Association Agreement were concluded since 2004; however, due to the political situation and position on both sides, the Agreement was never signed; Libya has had observer status since 1999).

98. EU-Turkey Relations, Eur. UniOn: EXTERnAl ACTION (last visited Aug. 19, 2014), http://www.eeas.europa.eu/turkey/index_en.htm, archived at http://perma.cc/U8JL-X2YG (Turkey and the European Community concluded a first generation AA with it in the 1960s, which resulted in a Customs Union that entered into force on January 1, 1996, and in 1999, Turkey was officially recognized as a candidate country for full membership of the EU).

99. Barcelona Process: Union for the Mediterranean, EUROPA: SUMMARIES OF EU LEGISLATION (last visited Aug. 19, 2014), http://europa.eu/legislation_summaries/external_ relations/relations_with_third_countries/mediterranean_partner_countries/rx0001_en.htm, archived at http://perma.cc/6YRY-6LCX. Also referred to as the Barcelona Process. Id. In 
launched in 1995 as a platform for regional economic, political, and social cooperation. ${ }^{100}$ An essential feature of the Euromed Partnership is the Association Agreements (AA) entered into between the EU and its Mediterranean Partners. ${ }^{101}$ The table below lists the current AAs.

\begin{tabular}{|l|l|l|}
\hline Country & Signed on: & Entry into force on: \\
\hline Algeria & $4 / 22 / 2002$ & $9 / 1 / 2005$ \\
\hline Egypt & $6 / 25 / 2001$ & $6 / 1 / 2004$ \\
\hline Israel & $11 / 20 / 1995$ & $6 / 1 / 2000$ \\
\hline Jordan & $11 / 24 / 1997$ & $5 / 1 / 2002$ \\
\hline Lebanon & $6 / 17 / 2002$ & $4 / 1 / 2006$ \\
\hline Morocco & $2 / 26 / 1996$ & $3 / 1 / 2000$ \\
\hline $\begin{array}{l}\text { Palestinian } \\
\text { Authority }\end{array}$ & $2 / 24 / 1997$ & $7 / 1 / 1997$ \\
\hline Tunisia & $7 / 17 / 1995$ & $3 / 1 / 1998^{103}$ \\
\hline
\end{tabular}

While the provisions of the Euromed AAs vary from one Partner to the other, they inevitably have certain common characteristics ${ }^{104}$ including the establishment of a Free Trade Area (also known as the Barcelona Process). ${ }^{105}$

2008, the Partnership was re-launched as a Union for the Mediterranean (UfM) to infuse new vitality and raise the political level of the strategic relationship. Id.

100. The EuroMed Partnership, EU NeIGHBOURHOOD Info CEnTRE (last visited Aug. 19, 2014), http://www.enpi-info.eu/medportal/content/340/About\%20the\%20EuroMed\%20 Partnership, archived at http://perma.cc/HJT8-LDEW.

101. Euromed - Euro Mediterranean Partnership, THE NAT'L ARCHIVES (last visited Aug. 19, 2014), http://webarchive.nationalarchives.gov.uk/+/http://www.dti.gov.uk/ europeandtrade/regional-trade/euregionaltradeagreementundernegotiation/eumediterranean/ page10110.html, archived at http://perma.cc/A44X-PEE9.

102. Euro-Mediterranean Interim Association Agreement on Trade and Cooperation between the European Community, of the One Part, and the Palestine Liberation Organization (PLO) for the Benefit of the Palestinian Authority of the West Bank and the Gaza Strip, of the Other Part was signed in 1997. Palestine, EUR. UNION: ExTERNAL ACTION (last visited Aug. 19, 2014), http://www.eeas.europa.eu/palestine/index_en.htm, archived at http://perma.cc/R5P3-DZ5H.

103. Trade Agreements, EUROPEAN COMMISSION, http://ec.europa.eu/trade/creatingopportunities/bilateral-relations/agreements/ (last visited Oct. 27, 2013, archived at http://perma.cc/U2YQ-8D43).

104. For comparison of the text of the AAs, see IÑIgo de Prada Leal \& JoAnna DeKa, Euro-Med Association AgreEments Implementation Guide (REFlex F) (2004).

105. Tenth Anniversary of the Euro-Mediterranean Partnership, EUROPA: SUMMARIES OF EU LEgislation (last visited Aug. 20, 2014), http://europa.eu/legislation_summaries/ external_relations/relations_with_third_countries/mediterranean_partner_countries/r10156_e n.htm, archived at http://perma.cc/32CT-44BD. The Euro-Mediterranean Partnership focuses on three main objectives: (1) creation of an area of peace and stability based on the principle of human rights and democracy; (2) creation of an area of shared prosperity through the progressive establishment of free trade between the EU and its Mediterranean partners and amongst the partners themselves; and (3) improvement of mutual understanding 
AAs are organized according to three pillars. ${ }^{106}$ The first is political, an essential element of which is the respect for human rights and democracy, an element that also provides for political dialogue. ${ }^{107}$ The second is the economic and financial pillar, pursuant to which free trade in goods (industrial and agricultural) is to be established between the EU and the Med Partner in accordance with WTO rules over a transitional period, which may last up to 12 years. ${ }^{108}$ Trade in services is also to be gradually liberalized. ${ }^{109}$ They include maintenance of a high level of protection for intellectual property rights, gradual liberalization of public procurement, adjustment of provisions relating to competition, state aid and monopolies, provisions on the liberalization of capital movements, and economic cooperation in a wide range of sectors. ${ }^{110}$ Under the third pillar of social and cultural cooperation, the AAs contain provisions on workers' rights and other social matters, as well as for the readmission of nationals and nonnationals illegally arriving in the territory of one party from that of another. ${ }^{111}$ The AAs also provide for EU financial assistance for the Med Partner(s), except Israel. ${ }^{112}$ The AAs also include procedures for the resolution of disputes relating to the application or interpretation of the Association Agreement. ${ }^{113}$

The Jordan-EU Association Agreement (AA) was signed in 1997, and it came into force on May 1, 2002 (prior to that Jordan's and the EU's (then

among the peoples of the region and the development of a free and flourishing civil society. Id.

106. See Press Release, European Commission, EU and Central America Sign Association Agreement (June 29, 2012), archived at http://perma.cc/W96E-ANVN.

107. Id.

108. Id.

109. Euro-Med services and right of establishment negotiations were launched in $2006 \backslash$ and have sense stalled due to the global economic crises and the political unrest in the Med Partner countries. In 2011, bilateral negations were opened with Jordan, Morocco, Tunisia and Egypt. Euro-Med Trade Talks in Marrakech Will Launch Services Talks and Boost FTA Plans, EU AT UN (last visited Aug. 20, 2014), http://www.eu-un.europa.eu/ articles/fr/article_5836_fr.htm, archived at http://perma.cc/7FDV-UCJJ; see also Press Release, European Commission, EU Agrees to Start Trade Negotiations with Egypt, Jordan, Morocco and Tunisia (Dec. 14, 2011), archived at http://perma.cc/D5V4-8FXD.

110. See Press Release, European Commission, Comprehensive Association Agreement between Central America and the European Union (Jun. 29, 2012), archived at http://perma.cc/G7KY-72GD.

111. See id.

112. European Neighbourhood \& Partnership Instrument, EUROPEAN COMMISSION (last updated Oct. 17, 2012), http://ec.europa.eu/europeaid/how/finance/enpi_en.htm, archived at http://perma.cc/DQ4D-UPH9 (EU financial aid to the Med Partners is governed by a unilateral policy and instrument of the European Neighbourhood Policy (ENP) and the European Neighbourhood and Partnership Instrument (ENPI)).

113. See Press Release, European Commission, Comprehensive Association Agreement between Central America and the European Union (Jun. 29, 2012), archived at http://perma.cc/G7KY-72GD. 
the EC) relations were governed by the 1977 Cooperation Agreement). ${ }^{114}$ Under the AA, an Association Council (headed by Jordan's Minster of Foreign Affairs) is established, as the political arm for cooperation with the power to amend certain provisions or arrangements (such as progressive tariff dismantlement schemes and amendments to the rules of origin $(\mathrm{ROO})) .{ }^{15}$ An Association Committee (headed by Jordan's Secretary General of the Ministry of Planning and International Cooperation) is also established as the technical arm for cooperation in addition to an institutionalized Economic Dialogue. ${ }^{116}$

The EU is also pursuing the establishment of a more efficient dispute settlement mechanism for the trade provisions of the Association Agreements. ${ }^{117}$ In this context regional negotiations were formally launched at the fifth Euro-Med Trade Ministerial Conference held in Marrakech on March 24, 2006. ${ }^{118}$ Jordan signed a Dispute Settlement Protocol in Brussels in June 2011, which created a dispute settlement process inspired by the WTO Dispute Settlement Understanding, replacing the less reliable diplomatic approach contained in Article 101 of the Jordan-EU AA, though only as related to trade issues. ${ }^{119}$

At the ninth Jordan-EU Association Council meeting held in Brussels on October 26, 2010, the EU agreed to grant Jordan the "Advanced Status," a designation that indicates closer ties in all areas; this includes deeper integration, which goes beyond removing tariffs to cover other issues of economic integration, investment, government procurement, and regulatory issues. ${ }^{120}$ Negotiations for the further liberalization of trade in services pursuant to article 40 of the AA will be embedded in the context of a comprehensive free trade area. ${ }^{121}$ Additionally, these negotiations will pursue the Agreement on Conformity Assessment and Acceptance

114. Jordan, COUNTRIES AND REGIONS (last updated May 13, 2014), http://ec.europa.eu/trade/creating-opportunities/bilateral-relations/countries/jordan/, archived at http://perma.cc/5DFA-R3YV.

115. Euro-Mediterranean Agreement Establishing an Association Between the European Community and its Member States, of the One Part, and the Hashimite Kingdom of Jordan, of the Other Part, Eur. Communities-Jordan, Nov. 24, 1997, O.J. (L129) 15/05/2002, archived at http://perma.cc/E97J-8ZLC [hereinafter Euro-Mediterranean Agreement].

116. Id. arts. 61, 92 .

117. Id. art. 97.

118. See 5th Euromed Trade Ministerial Conference Conclusions (2006), archived at http://perma.cc/PQD5-2MBZ.

119. European Council TV Newsroom, Signing Ceremony of the EU-Jordan Dispute Settlement Protocol, (Nov. 2, 2011), http://tvnewsroom.consilium.europa.eu/video/signingceremony-of-the-eu-jordan-dispute-settlement-protocol, archived at http://perma.cc/K3M8WXLP.

120. Statement by the European Union, Ninth Meeting of the EU-Jordan Association Council, Statement by the European Union (Oct. 26, 2010), 15539/10, PRESSE 288 archived at $\mathrm{http}: / /$ perma.cc/HEX9-T53S.

121. See generally Euro-Mediterranean Agreement, supra note 115. 
(ACAA), which is an agreement entailing regulatory convergence in line with EU standards on industrial products. ${ }^{12}$

On the sectoral level, Jordan and the EU have entered into a number of bilateral arrangements to enhance cooperation in energy, aviation, and air management. ${ }^{123}$ Furthermore, towards the achievement of the Euromed Free Trade Area, Jordan has entered into bilateral agreements with all the Euromed partners. ${ }^{124}$ The agreements with the EU cover issues such as intellectual property, competition, state aid, government procurement and dispute settlement, and related institutional provisions at the political and technical levels that are central to the management and progression of the partnerships. ${ }^{125}$ In this Article we have elected to offer a snapshot of the Rules of Origin (ROOs) and Services.

\section{Rules of Origin (ROOs)}

ROOs have an important role within FTAs. Simply put, ROOs specify the origin of traded goods, thus countries can determine the goods which should or should not benefit from free trade rules. This eligibility mechanism would prevent "Trade Deflection." 26 In the context of the

122. Agreements on Conformity Assessment and Acceptance of Industrial Products (ACAA), EUROPEAN COMMISSION (last updated Oct. 28, 2013), http://ec.europa.eu/enterprise/ policies/single-market-goods/international-aspects/acaa-neighbouring-countries/index_en.htm, archived at $\mathrm{http}: / /$ perma.cc/T6AJ-R75H.

123. Press Release, European Commission, Developing External Energy Policy for the EU (Nov. 30, 2007), archived at http://perma.cc/3HN2-5S6Z. These are the 2007 Joint Declarations on Energy Cooperation that provide a basis for enhancing energy relations and include a possibility for cooperation on nuclear safety: the 2008 Horizontal Aviation Agreement as a first step to integrate Jordan further into the European air transport market, pursuant to which Jordan and the EU, on December 15, 2010 signed a Comprehensive Air Services Agreement, which will establish a "Euro Mediterranean Aviation Area" based on common rules and a liberalization of the air markets. Press Release, European Community Signs a Science \& Technology Cooperation Agreement with Jordan (Nov. 30, 2009), archived at http://perma.cc/4LGZ-YSFM. Also the 2009 Science and Technology (S\&T) Cooperation Agreement will help structure and enhance S\&T cooperation in areas of common interest. See Press Release, Europa, EU and Jordan Sign Air Transport Agreement (Dec. 15, 2010), archived at $\mathrm{http}: / /$ perma.cc/C43A-4829.

124. Jordan, supra note 114.

125. Jordan-EU Association Agreement Overview: Executive Summary, Ministry of Planning \& Int'l Cooperation (last visited Aug. 20, 2014), http://www.mop.gov.jo/ pages.php?menu_id=228, archived at $\mathrm{http}: / /$ perma.cc/GA93-K7MA.

126. The creation of preferential trade areas "normally leads to the expansion of trade between its members, but economic theory postulates that a share of the increased trade experienced by participants is merely due to a redirection of their trade, and not increased trade due to the arrangement. This effect can be demonstrated convincingly in models. In practice, trade diversion has always been very difficult to isolate because of other factors. These include technological innovation, global reduction in tariffs, changes in investment policies, etc." See Dictionary of Trade Policy Terms, supra note 1. 
Euromed partnership, ROOs are central to the establishment of the Euromed free trade area, and the AAs include agreed-upon ROOs in the form of Protocols attached to each agreement. ${ }^{127}$ Initially, however, the AA ROO protocols of the Med Partners were not harmonized. "For example, the ROOs applicable to the [AAs] with Egypt and Jordan were virtually identical to the Pan-European rules, whereas the agreements with Morocco and Tunisia were slightly different for certain product categories."

The Pan-European ROOs model emerged in the 1990s as an effort to harmonize the origin rules embedded in the EU's different/various FTAs. ${ }^{129}$ In 1994, the European Commission (EC) submitted a report presenting a strategy for harmonizing the preferential ROOs to reduce the underutilization of trade preferences and to maximize the gains from trade in a European context. ${ }^{130}$ At the Euro-Med Trade Ministerial Meeting held

127. Patricia Augier et Al., The EU-Med Partnership and Rules of Origin 1 (2003), archived at http://perma.cc/MT8Z-B8Y9 ("All preferential trading arrangements have detailed protocols on rules of origin").

128. Id. at 1.1 .

129. Teruo Ujiie, Rules of Origin: Conceptual Explorations and Lessons from the Generalized System of Preferences (Asian Dev. Bank, ERD, Working Paper No. 89, 2006), archived at http://perma.cc/RHK8-G72U. The EU is the only regional bloc that also adopted a common set of non-preferential ROOs. System of Pan-Euro-Mediterranean Cumulation, EUROPEAN COMMISSION (last updated July 27, 2014), http://ec.europa.eu/taxation_customs/ customs/customs_duties/rules_origin/preferential/article_783_en.htm, archived at http://perma.cc/3PM7-JLYD. "Goods whose production involved more than one country shall be deemed to originate in the country where they underwent their last, substantial, economically justified processing or working in an undertaking equipped for that purpose, and resulting in the manufacture of a new product or representing an important stage of manufacture. This basic concept is interpreted into process criterion, percentage criterion, or combination of these two criteria in determining the country of origin. The importance of the EU non-preferential rules of origin lay down specific rules on a product-specific basis reflecting the EU's interest such as radios, televisions, tape recorders, integrated circuits, photocopiers, and textiles and clothing." Id. at 16. The EU now applies its MFN tariff to only nine trading partners. These include: Australia, Canada, Chinese Taipei, Hong Kong, China, Japan, Korea, New Zealand, Singapore, and the US. Third Euromed Trade Ministerial: Stepping Stones Towards Greater Regional Integration, EUROPEAN COMMISSION (last updated July 4, 2003), http://trade.ec.europa.eu/doclib/events/index.cfm?id=179, archived at http://perma.cc/S2QN-STS6.

130. Communication from the Commission to the Council Concerning the Unification of Rules of Origin in Preferential Trade Between the Community, the Central and East European Countries and the EFTA Countries (Nov. 30, 1994), archived at http://perma.cc/3A7K-UDPF. The European Council adopted the proposal in December 1994. By 1997, harmonized protocols replaced the preexisting ones, covering an area composed of the EU, the European Economic Area (EEA), Switzerland and the associated Central and Eastern European Countries (CEEC). EFTA through the Years, EFTA (last visited Aug. 20, 2014), http://www.efta.int/about-efta/history, archived at http://perma.cc/KJP8-LRQQ. The EU's decision to harmonize its preferential ROOs extended to the FTAs with the Med Partner countries; this approach was endorsed in March 2002 at the EU-Mediterranean Trade Ministerial Conference held in Toledo where, in 
in Palermo on July 7, 2003, the decision was taken to replace the ROOs protocols contained in the previously adopted AAs, with the "Pan-EuroMediterranean protocol on rules of origin."131

Since then, the Pan-Euro-Med Protocol has been available for the progressive adoption by the Med Partners. ${ }^{132}$ Jordan adopted the Protocol in $2006 .{ }^{133}$ The creation of the Pan-Euro-Med ROOs, through the extension of the Pan-Euro zone to the Med Partners (Algeria, Egypt, Israel, Jordan, Lebanon, Morocco, Syria, Tunisia, the Palestinian Authority, and the Faroe Islands), allows for diagonal cumulation between these territories. ${ }^{134}$ This means that goods consisting of components made in more than one participating country are treated in the same way as domestically produced goods. In other words, material can be sourced and manufactured in a number of countries within the Pan-Euro-Med cumulation area without the finished product losing the benefit of preferential customs tariffs when it enters the country of destination. ${ }^{135}$ However, the generalization of the system of diagonal cumulation requires the fulfillment of the following three conditions: (i) FTAs with identical ROOs should be in place between both the EU and the Southern Mediterranean countries; (ii) among these countries, all administrative procedures have to be harmonized; and (iii) all draw-back provisions should be withdrawn. ${ }^{136}$

Additionally, materials and products must have acquired originating status by the application of rules of origin identical to those given in this Protocol. ${ }^{137}$ The conditions aim at ensuring that a set of harmonized

principle, it was agreed to extend the Pan-European system of cumulation of rules of origin to the Barcelona group of countries. Press Release, Conclusions of the Presidency - EuroMediterranean Ministerial Conference on TRADE Toledo, 19 March 2002 (Mar. 19, 2002), archived at http://perma.cc/9P67-SEHU.

131. Council Regulation No. 1617/2006, 2006 O.J. (L 300) 5 (EC) archived at http://perma.cc/WLE6-2WXX.

132. Council Decision 9526/5 preamble, 2002 O.J. (L 129) 3, archived at http://perma.cc/728Y-6DW4 ("In accordance with the Joint Declaration on Article 28 of the Agreement, the extension of the system of cumulation is desirable making it possible to use materials originating in the Community, Bulgaria, Romania, Iceland, Norway, Switzerland (including Liechtenstein), the Faeroe Islands, Turkey or in any other country which is a participant in the Euro-Mediterranean partnership, based on the Barcelona Declaration adopted at the Euro-Mediterranean Conference held on 27 and 28 November 1995, in order to develop trade and promote regional integration").

133. See generally, European Commission, Taxation and Customs Union, EuRoPEAN COMMISSION (last updated July 31, 2014), http://ec.europa.eu/taxation_customs/, archived at http://perma.cc/RJ2A-HQLV.

134. Council Decision 9526/5, supra note 132.

135. See Explanatory Notes Concerning the Pan-Euro-Mediterranean Protocols on Rules of Origin, 2007 (C 83) 1, archived at http://perma.cc/K6N8-JFTJ.

136. Common Provisions, EuRoPEAN COMMISsion (last updated July 27, 2014), http://ec.europa.eu/taxation_customs/customs/customs_duties/rules_origin/preferential/articl e_774_en.htm\#no_drawback_rule, archived at http://perma.cc/3KDN-L2UY.

137. See Regional Convention on Pan-Euro-Mediterranean Preferential Rules of Origin, June 15, 2011, archived at http://perma.cc/5W2Z-RT8W. 
preferential ROOs, i.e., the Pan-Euro-Med ROOs, is adopted by all partner countries, which will allow for the implementation of cumulation among several of these partners, thereby paving the way for the establishment of the Euro-Med Free Trade Area. ${ }^{138}$

At the region-to-region level, the EU has introduced the Regional Convention on preferential Pan-Euro-Med rules of origin that was opened for signature as of June 15, 2011. ${ }^{139}$ This Convention is to replace the network of bilateral protocols, whereby the bilateral FTAs, whether those of the EU and its different partners (which, according to the EU website, number about sixty $)^{140}$ or those between its partners, would no longer contain an annex on ROOs, but would instead incorporate by reference, the rules of the Regional Convention. ${ }^{141}$ Indeed, many of the Med Partner countries, including Jordan, have long been calling for the simplification of the Pan-Euro-Med rules of origin system, which remains too complex, ${ }^{142}$ accordingly, all Med Partner countries have signed the Regional Convention, including Jordan. ${ }^{143}$

Jordan's utilization of the benefit afforded by the ROOs Protocol remains below expectation, due to a number of factors, such as the lack of sufficient businesses that are girded to take advantage of the ROOs regime. ${ }^{144}$ The challenge, therefore, is to develop the local capacities as well as the industrial linkages, whether at the national or regional level, to be

138. See Joseph F. Francois et al., European Union - Developing Country FTAs: Overview and Analysis, 33 World Development 1545 (2005), archived at http://perma.cc/9HMV-NEAS. Other significant FTAs that include the Pan-Euro-Med ROOs are: the Agadir Agreement (between Egypt, Jordan, Morocco and Tunisia), Egypt - Turkey, Israel - EFTA, Israel - Turkey; Jordan - Israel (Agreement of Trading and Economic Cooperation between the Hashemite Kingdom of Jordan and the Government of the State of Israel), Jordan - Turkey, Jordan-EFTA, Morocco - Turkey and Tunisia - Turkey. Regional Convention on Pan-Euro-Mediterranean Preferential Rules of Origin, June 15, 2011, archived at http://perma.cc/5W2Z-RT8W.

139. System of Pan-Euro-Mediterranean Cumulation, supra note 129.

140. Regional Convention on Pan-Euro-Mediterranean Preferential Rules of Origin, at preamble, June 15, 2011, archived at http://perma.cc/5W2Z-RT8W.

141. Id.

142. Stefano Inama, Rules of Origin in International Trade 555 (2009).

143. See European Commission Taxation and Customs Union, EuropeAn COMMISSION, www.ec.europa.eu/taxation_customs/ (last visited Oct. 14, 2013, archived at http://perma.cc/5V5A-BFFS); see also Regional Convention on Pan-Euro-Mediterranean Preferential Rules of Origin, June 15, 2011, archived at http://perma.cc/5W2Z-RT8W.

144. It should be noted here that this paragraph only addresses the issue concerning the Pan-Euro-Med ROOs and does not touch upon the overall trade relations between Jordan and Israel, such as the 1997 agreement establishing the Qualified Industrial Zones (QIZ), were in 2004 fifty manufacturing plants created 45,000 new jobs and increased Jordan's exports to the US, while Israeli inputs into production exported to America through the QIZs totaled \$65 million. Deputy Prime Minister Ehud Olmert, Israel's Redeployment and Economic Relations with Its Arab Neighbors, 3 JERUSALEM IsSUE BRIEF (2004), archived at http://perma.cc/YP8P-YLWJ. 
able to effectively penetrate EU markets. This requires long-term planning and covering issues including TBTs to marketing. Simply put, Jordan's industries need to develop and modernize to be able to meet the demands of the sophisticated and complex EU markets. The following visuals show the types of goods that do not benefit from Jordan's preferential ROOs, with the first showing volume in million Jordanian Dinars. ${ }^{145}$

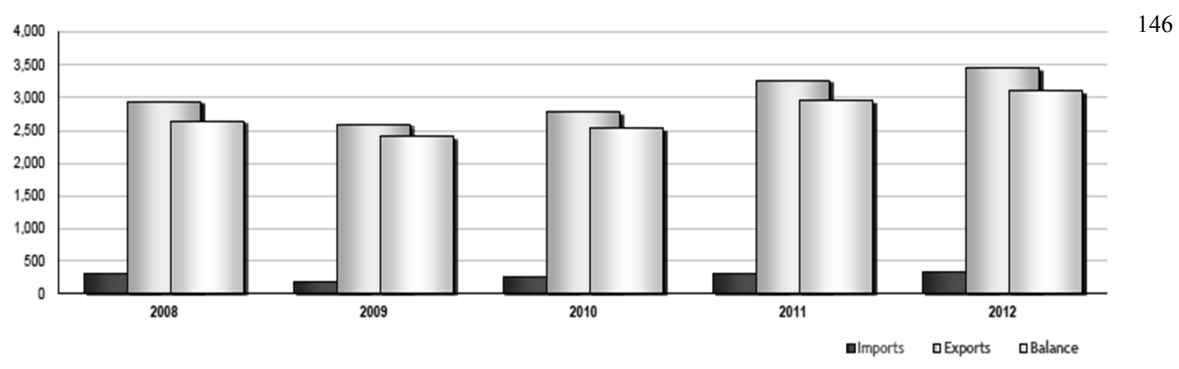

\begin{tabular}{|c|c|c|c|c|c|c|c|}
\hline \multirow{2}{*}{$\begin{array}{l}\text { SITC Rev.3 (UN, WTO/TS) \& AMA/NAMA** (WTO) } \\
\text { Product Groups }\end{array}$} & \multicolumn{2}{|c|}{2008} & \multicolumn{2}{|c|}{2010} & \multicolumn{2}{|c|}{2012} & \multirow{2}{*}{$\begin{array}{l}\text { Share of } \\
\text { Partner in EU } \\
\text { Imports } 2012\end{array}$} \\
\hline & Millions euro & $\%$ & Millions euro & $\%$ & Millions euro & $\%$ & \\
\hline 0000 - Total & 298 & $100.0 \%$ & 249 & $100.0 \%$ & 342 & $100.0 \%$ & $0.0 \%$ \\
\hline 1000 - Primary products & 95 & $31.9 \%$ & 81 & $32.7 \%$ & 147 & $43.0 \%$ & $0.0 \%$ \\
\hline $\begin{array}{l}11000 \text { - Argicituruala products (food (incl. Fish) \& Raw Materials) } \\
1200 \text {. Fuels and mining products }\end{array}$ & ${ }_{78}^{17}$ & $\begin{array}{l}5.7 \% \\
26.2 \%\end{array}$ & $\begin{array}{l}19 \\
63\end{array}$ & $\begin{array}{r}7.5 \% \\
25.2 \%\end{array}$ & ${ }_{124}^{23}$ & $\begin{array}{r}6.8 \% \\
36.2 \% \\
\end{array}$ & $\begin{array}{l}0.0 \% \\
0.0 \%\end{array}$ \\
\hline 1200 - Fuels and mining products & 78 & $26.2 \%$ & & $25.2 \%$ & 124 & $36.2 \%$ & $0.0 \%$ \\
\hline 2000 - Manufactures & 189 & $63.4 \%$ & 139 & $55.7 \%$ & 164 & $48.1 \%$ & $0.0 \%$ \\
\hline 2100 - Iron and steel & 0 & $0.0 \%$ & 0 & $0.0 \%$ & 0 & $0.1 \%$ & $0.0 \%$ \\
\hline 2200 - Chemicals & 105 & $35.3 \%$ & 63 & $25.4 \%$ & 97 & $28.4 \%$ & $0.1 \%$ \\
\hline 2300 - Other semi-manufactures & 14 & $4.6 \%$ & 10 & $3.9 \%$ & 8 & $2.3 \%$ & $0.0 \%$ \\
\hline 2400 - Machinery and transport equipment & 45 & $15.0 \%$ & 38 & $15.1 \%$ & 32 & $9.3 \%$ & $0.0 \%$ \\
\hline 2410 - Office and telecommunication equipment & 6 & $2.0 \%$ & 5 & $1.9 \%$ & 5 & $1.5 \%$ & $0.0 \%$ \\
\hline 2420 - Transport equipment & 23 & $7.6 \%$ & 10 & $4.1 \%$ & 12 & $3.6 \%$ & $0.0 \%$ \\
\hline 2430 - Other machinery & 16 & $5.4 \%$ & 23 & $9.1 \%$ & 14 & $4.2 \%$ & $0.0 \%$ \\
\hline 2500 - Textiles & 1 & $0.5 \%$ & 3 & $1.0 \%$ & 1 & $0.2 \%$ & $0.0 \%$ \\
\hline 2600 - Clothing & 10 & $3.5 \%$ & 10 & $3.8 \%$ & 10 & $3.0 \%$ & $0.0 \%$ \\
\hline 2700 - Other manufactures & 14 & $4.5 \%$ & 16 & $6.5 \%$ & 16 & $4.7 \%$ & $0.0 \%$ \\
\hline 3000 - Other products & 13 & $4.3 \%$ & 28 & $11.4 \%$ & 27 & $7.8 \%$ & $0.0 \%$ \\
\hline Agricultural Products (AMA) & 17 & $5.7 \%$ & 18 & $7.4 \%$ & 22 & $6.5 \%$ & $0.0 \%$ \\
\hline Non-Agricultural Products (NAMA) & 276 & $92.4 \%$ & 226 & $90.7 \%$ & 310 & $90.7 \%$ & $0.0 \%$ \\
\hline Other Products & 6 & $1.9 \%$ & 5 & $1.9 \%$ & 10 & $2.8 \%$ & $0.1 \%$ \\
\hline
\end{tabular}

\section{Services}

The EU-MED agreements contain rendezvous clauses for the liberalization of trade in services. ${ }^{147}$ The Jordan-EU Association Agreement contains a more sophisticated chapter on "services and right of establishment" vis-a-vis other Med Partners' AAs, which are generally limited to the provision on simply pursuing services liberalization. ${ }^{148}$ This Article holds that the Jordan-EU's AA approach to services liberalization

145. European Commission, European Union, Trade in GoOdS With Jordan (2014), archived at http://perma.cc/GJH4-Y2WY [hereinafter TRADE IN GOODS WITH JORDAN]; Jordan, supra note 114.

146. TRADE IN GOODS WITH JORDAN, supra note 145.

147. European Commission, Euro-Med Association Agreements: Implementation GuIDE REFLEX F 61-74 (2004), archived at http://perma.cc/7UY5-8JSY; see also EUROPEAN COMMISSION, UPDATE: INTERIM ECONOMIC PARTNERShIP AgREEMENTS (2007), archived at http://perma.cc/DL2U-NTC6.

148. See Agreements, EUROPEAN COMMISSION, http://ec.europa.eu/trade/creatingopportunities/bilateral-relations/agreements/\#_mediterranean (last visited Oct. 14, 2013, archived at http://perma.cc/ABG-6QDV). 
follows from the GATS, as it covers the four known modes of supply, but it also adds the "right of establishment." "This is an example of how the EU approach differs from the WTO's four modes formula of economic integration. ${ }^{150}$ By using the "right of establishment" approach, the EU has effectively introduced different forms of investment, including acquisitions, mergers, and takeovers, to non-services activities (such as commerce or manufacturing). ${ }^{151}$

Pursuant to the aforementioned rendezvous clause of the AAs (article 40 of the Jordan-EU AA) at the Euromed Trade Ministerial Conferences in Palermo on July 7, 2003, Ministers agreed on establishing a Framework Protocol for the liberalization of trade in services common to all Euromed Partners. ${ }^{152}$ Throughout 2006-2008, a number of negotiation rounds were held. ${ }^{153}$ Following the Ministers' decision at the last Euromed Trade Ministerial Conference in Brussels on December 9, 2009, ${ }^{154}$ bilateral negotiations on the liberalization of trade in services and the right of establishment were launched with Egypt, Morocco, and Tunisia, and with Israel in July. ${ }^{155}$ Since then, a number of informal consultations have taken place between Jordan and the EU, including the development of a "Scoping Paper" addressing the scope of issues to be covered by the future negotiation. ${ }^{156}$

\section{B. The Agadir Agreement}

With EU support, Egypt, Jordan, Morocco, and Tunisia entered into the Arab Mediterranean Free Trade Agreement (the Agadir Agreement), a

149. The General Agreement on Trade in Services (GATS): Objectives, Coverage and

Disciplines, WORLD TRADE ORGANIZATION, http://www.wto.org/english/tratop_e/ serv_e/gatsqa_e.htm (last visited Oct. 12, 2013, archived at http://perma.cc/JL9K-9UWP).

150. For WTO's modes of service providing see Services: Rules for Growth and Investments, WORLD TRADE ORG., http://www.wto.org/english/thewto_e/ whatis_e/tif_e/agrm6_e.htm (last visited Aug. 25, 2014, archived at http://perma.cc/96FWKUEL).

151. See 6.5.1. Right of establishment in the EU, EuropediA, http://www.europedia.moussis.eu/books/Book_2/3/6/05/1/?all=1 (last visited Aug. 25, 2014, archived at http://perma.cc/P742-8TLF).

152. Conclusions of the Euro-Mediterranean Trade Ministerial Conference, July 7, 2003, EUROPA, http://trade.ec.europa.eu/doclib/docs/2003/september/tradoc_113840.pdf, archived at http://perma.cc/G6W-B4ZF.

153. Press Release, 8th Union for the Mediterranean Trade Ministerial Conference, Dec. 9, 2009, EUROPA, http://europa.eu/rapid/press-release_MEMO-09-547_en.htm, archived at http://perma.cc/R5MT-7GNZ.

154. Id.

155. $I d$.

156. Press Release, ENP Package, Country Progress Report - Jordan, May 15, 2012, EUROPA, http://europa.eu/rapid/press-release_MEMO-12-336_en.htm?locale=en, archived at http://perma.cc/AXL3-FQ43. 
regional plurilateral trade agreement. ${ }^{157}$ In February 2004, this FTA was signed in Rabat and entered into force in July 2006. ${ }^{158}$ The Agreement creates an integrated market of over " 100 million people with a combined domestic product of nearly $€ 150$ billion." 159 It aims at the total elimination of customs tariffs, the harmonization of laws in economic matters, invigoration of trade exchanges, promotion of industries, stimulating economic activities and employment, and improving productivity and living standards. ${ }^{160}$ Moreover, the Agreement covers services. ${ }^{161}$

The ROOs adopted by the Agadir Agreement are the Pan-Euro-Med ROOs, which allow for diagonal cumulation between the Agadir countries and the EU. ${ }^{162}$ The Agadir ROOs protocol is identical to the Pan-Euro-Med protocols of the AAs, save in one aspect related to the government agency authorized to issue the proof of origin. ${ }^{163}$ Article (16) of Annex II to the Agadir Agreement provides that the Certificate of Origin (CO) may be issued by the "customs authority or the relevant authorized government authority," while under the Pan-Euro-Med procedure, such proof of origin may only be issued by the customs authority. ${ }^{164}$

\section{Jordan-EFTA FTA}

The FTA between Jordan and the European Free Trade Association (EFTA) (composed of Iceland, Liechtenstein, Norway, and Switzerland) was signed in June 2001 and entered into force in September 2002. ${ }^{165}$ This Agreement covers goods trade and contains a 12-year translational period. ${ }^{166}$ Hence, by 2014 , all customs duties on trade in industrial goods and fish and other marine products will be eliminated, excluding some

157. See Greater Arab Free Trade Area (GAFTA), supra note 83. See Tomer Broude, Regional Economic Integration in the Middle East and North Africa: A Primer, 2009 EuR. Y.B. OF INT'L ECON. L. 1, 6-7 (2009).

158. Agadir Technical Unit, Workshop on Challenges and Opportunities for the Textiles and Clothing Sector in the Euro-Mediterranean Region (Mar. 12, 13, 2012), archived at http://perma.cc/FF5E-Z7QE; it should also be noted that this agreement has not been notified to the WTO. Id.

159. Commissioner Patten's Speech on the Signature of the Agadir Agreement at the EP, EUROPA (Feb. 26, 2004), http://www.eu-un.europa.eu/articles/en/article_3243_en.htm, archived at http://perma.cc/5C9D-D4BH.

160. Id.

161. Id.

162. Id.

163. See The Agadir Agreement, at Annex II, Feb. 25, 2004.

164. Id.; Euro-Mediterranean Agreement, supra note 115.

165. Jordan, EFTA, http://www.efta.int/free-trade/free-trade-agreements/jordan (last visited Aug. 28, 2014, archived at http://perma.cc/ABG6-NJ2W).

166. Agreement Between the EFTA States and the Hashemite Kingdom of Jordan art. 22.5, June 21, 2001, archived at http://perma.cc/42W2-X6UA [hereinafter EFTA-Jordan Agreement]. 
targeted products such as beverages and tobacco on which tariff protection levels are generally maintained. ${ }^{167}$ The Agreement contains bilateral agreement on agricultural products between Jordan and the individual EFTA states. ${ }^{168}$

With respect to ROOs incorporated into the Jordan-EFTA FTA, they are the standardized European rules of the Pan-Euro-Med ROOs, granting diagonal cumulation in the same manner as the Agadir Agreement. ${ }^{169}$

Article 28 on services and investment provides that, in the context of the Euro-Med integration, the parties will cooperate, with the aim of services liberalization and promoting investment. ${ }^{170}$ However, services negotiations have gone nowhere thus far. ${ }^{171}$

\section{Jordan-Turkey FTA}

The Jordan-Turkey FTA was signed in December 2009 and entered into force in March 2011. ${ }^{172}$ This Agreement, also applying the Pan-EuroMed ROOs, covers goods trade and initiates a gradual reduction of tariffs over twelve years. ${ }^{173}$ However, the FTA contains quotas and an extensive negative list of goods not benefiting immediately from the agreed preferential tariff. ${ }^{174}$ Article 36 of the Agreement envisions the possible future liberalization of trade in services, taking into account the GATS as well as ongoing negotiations within the WTO. ${ }^{175}$

Article 48 provides for a dispute settlement procedure that is political in nature but includes the establishment of a three-member tribunal and offers the complaining party the right to take measures. ${ }^{176}$ The article also foresees the development of detailed rules for this arbitration tribunal procedure. $^{177}$

167. See Decision of the EFTA-Jordan Joint Committee, at annex to protocol B, Apr. 20, 2012, archived at $\mathrm{http}: / /$ perma.cc/XV3-HE69.

168. See EFTA-Jordan Agreement, supra note 166, art. 13.

169. EFTA-Jordan Agreement, supra note 166, art. 4.

170. EFTA-Jordan Agreement, supra note 166, art. 28.

171. Agreement on the European Economic Area, Mar. 17, 1993, 37 I.L.M. 572, archived at http://perma.cc/F6NS-4AT3.

172. The Association Agreement Establishing a Free Trade Area Between the Hashemite Kingdom of Jordan and the Republic of Turkey, Dec. 1, 2009, archived at http://perma.cc/K6MG-W5XM.

173. Id. art. 2.

174. Id. Annex II.

175. Id.

176. Id. art. 25 .

177. Id. 


\section{E. Greater Arab Free Trade Agreement (GAFTA)}

At the Arab regional level, Jordan is a member of the Greater Arab Free Trade Agreement (GAFTA), which covers full liberalization of trade in goods among the seventeen Arab League member states (Algeria, Bahrain, Egypt, Iraq, Kuwait, Lebanon, Libya, Morocco, Oman, Palestine, Qatar, Saudi Arabia, Sudan, Syria, Tunisia, United Arab Emirates, and Yemen). ${ }^{178}$

With regard to the ROOs, GAFTA states decided to adopt more stringent origin rules stemming from the desire, as well as the need, to confront trade deflection, and these rules are envisioned to be part of the work plan for establishing the free trade area. ${ }^{179}$ The adoption of GAFTA ROOs Protocols is based on the Pan-Euro-Med Model. ${ }^{180}$

Regarding services, in 2003, the Arab League Social and Economic Council approved Draft General Provisions. ${ }^{181}$ However, except for Jordanian-Egyptian bilateral offers to liberalize three services sectors (computer, education, and telecommunications), little progress has been made.

\section{F. Jordan-US FTA}

The Jordan-US FTA was signed in October 2000 and entered into force in December 2001. ${ }^{182}$ The Agreement was the United States' fourth free trade agreement and its first ever with an Arab state. ${ }^{183}$ The FTA provides for significant and extensive liberalization across a wide spectrum of trade issues; it eliminates all tariff and non-tariff barriers to bilateral trade in virtually all industrial goods and agricultural products within ten years. ${ }^{184}$ Electronic commerce is explicitly covered in the Joint Statement on Electronic Commerce, whereby both parties are committed to promoting a

178. Javad Abedini \& Nicolas Péridy, The Greater Arab Free Trade Area (GAFTA): An Estimation of the Trade Effects 23 J. OF ECON. INTEGRATION 848 (2008).

179. For text of the GAFTA Declaration see Greater Arab Free Trade Area (GAFTA), supra note 83 .

180. The Arab NGo Network for Development, Free Trade Agreements in the ARAB REGION 8 (2006), archived at http://perma.cc/WT39-YUBY.

181. Id. at 15 .

182. U.S.-Jordan FTA, supra note 65.

183. Abdul Quader Shaikh, Bilateral Accords and U.S. Trade with the Middle East: A Track Record of Success, INT'L TRADE ADMIN, http://trade.gov/press/publications/ newsletters/ita_0408/middle-east_0408.asp (last visited Aug. 28, 2014, archived at http://perma.cc/6F44-6T79) (since then, the US has entered into an FTA with Morocco, Bahrain, and Oman).

184. See Press Release, The White House: Office of the Press Secretary, Fact Sheet: U.S.-Jordan Free Trade Agreement (Sept. 28, 2001), archived at http://perma.cc/LJ22AFC4; see U.S.-Jordan FTA, supra note 65. 
liberalized trade environment for electronic commerce that should encourage investment in new technologies and stimulate the innovative use of networks to deliver products and services. ${ }^{185}$ "Both countries agreed to avoid imposing customs duties on electronic transmissions, [to avoid] imposing unnecessary barriers to market access for digitized products, and [to avoid] impeding the ability to deliver services through electronic means." ${ }^{, 186}$ A separate Memorandum of Understanding on Transparency in Dispute Settlement was also established. ${ }^{187}$ The Agreement also deals, inter alia, with intellectual property, trade in services, electronic commerce, government procurement and dispute settlement, as well as environmental and labor issues. ${ }^{188}$ In this Article, the novel issue of labor and the issue of rules of origins will be highlighted.

\section{Labor}

Specific legal features of the Agreement include labor provisions within the body of the FTA, which not only reaffirm the parties' respect and enforcement of core labor standards, but also support this reaffirmation by a dispute settlement process. ${ }^{189}$ In May 2006, the National Labor Committee issued a report ${ }^{190}$ stating that foreign workers in the Qualifying Industrial Zones (QIZ) were forced to work long and arduous shifts in unhealthy conditions while being paid below-poverty wages. ${ }^{191}$ At the same time, employers were withholding workers' paychecks and passports, in effect

185. See Press Release, The White House: Office of the Press Secretary, Fact Sheet: U.S.-Jordan Free Trade Agreement (Sept. 28, 2001), archived at http://perma.cc/LJ22AFC4.

186. MONTAgUe J. LORD, ECONOMIC IMPACT AND IMPLiCATIONS FOR JORDAN OF THE U.S. - Jordan FreE TRAde AgreEMENT (2001), archived at http://perma.cc/5CN5-LJEQ.

187. Office of the United States Trade Representative, Memorandum of Understanding on Transparency in Dispute Settlement Under the Agreement Between the United States and Jordan on the Establishment of a Free Trade Area (2000), archived at http://perma.cc/H3JH-38S2.

188. Jordan FTA, OFFICE OF THE US TRADE REP., http://www.ustr.gov/tradeagreements/free-trade-agreements/jordan-fta/final-text (last visited Aug. 28, 2014, archived at http://perma.cc/YT3V-Q2PN). Jordan also has an FTA with Singapore (2004) which contains agreed origin determination criteria. Agreement Between the Government of the Hashemite Kingdom of Jordan and the Government of the Republic of Singapore on the Establishment of a Free Trade Area, Jordan-Sing., May 16, 2004, archived at http://perma.cc/8WYE-EP24.

189. U.S.-Jordan FTA, supra note 65, art. 6.

190. See AFL-CIO, Home Page, AFL-CIO, http://www.aflcio.org (last visited Aug. 28, 2014, archived at http://perma.cc/MDM-433C).

191. U.S. Jordan Free Trade Agreement Descends into Human Trafficking \& Involuntary Servitude, Institute FOR Global LABOUR AND Human Rights (May 2006), http://www.globallabourrights.org/reports?id=0619, archived at http://perma.cc/5MMYY6EQ. 
making them virtual prisoners and slave workers. ${ }^{192}$ Put differently, that report and others like it accused Jordan of ignoring its responsibilities under the FTA and claim the United States has done little to nothing to enforce the labor provision of the Agreement. ${ }^{193}$

The issue of trade and core labor standards has been the subject of intense debate both among and within certain WTO member governments. ${ }^{194}$ The proposal to bring labor standards within the WTO rules and disciplines is a controversial one, in which no clear consensus exists among the WTO Members. ${ }^{195}$ In the alternative, proponents of the WTO proposal to include core labor standards within the WTO's competences have moved to build labor provisions that aim to promote and protect workers' rights into the fabric of their trade agreements. ${ }^{196}$ Article 6 of the Jordan-US FTA is such a provision. ${ }^{197}$ The obligations placed on Jordan are two-fold: the first is to adopt or modify its domestic labor laws and regulations in line with Jordan's international obligations and internationally recognized core labor rights. ${ }^{198}$ The second is to enforce its labor laws and not to relax domestic legal enforcement in favor of encouraging trade with the other party. ${ }^{199}$

The FTA allows all violations of the Agreement, including labor rights, to be remedied through "appropriate and commensurate

192. See Bremen Donovan, The Made and the Madame: Rights for Migrant Workers in Jordan, NAMATI: INNOVATIONS IN LEgAL EMPOWERMENT (Feb. 18, 2014), http://www.namati.org/entry/the-maid-and-the-madame-rights-for-migrant-workers-injordan/, archived at http://perma.cc/YM63-8NXZ.

193. Hashemite Kingdom of Jordan, Human Trafficking \& Modern-Day Slavery, http://gvnet.com/humantrafficking/Jordan.htm (last visited Aug. 29, 2014, archived at http://perma.cc/G9Q4-FSQM).

194. Trade and Labour Standards Subject of Intense Debate, World TradE OrG., http://www.wto.org/english/thewto_e/minist_e/min99_e/english/about_e/18lab_e.htm (last visited Aug. 29, 2014, archived at http://perma.cc/WL54-EAUB).

195. Id. (at the first WTO Ministerial Conference in Singapore in December 1996, the issue was taken up and addressed in the Ministerial Declaration. At Singapore, Ministers stated: "We renew our commitment to the observance of internationally recognized core labor standards. The International Labor Organization (ILO) is the competent body to set and deal with these standards, and we affirm our support for its work in promoting them. We believe that economic growth and development fostered by increased trade and further trade liberalization contribute to the promotion of these standards. We reject the use of labor standards for protectionist purposes, and agree that the comparative advantage of countries, particularly low-wage developing countries, must in no way be put into question. In this regard, we note that the WTO and ILO Secretariats will continue their existing collaboration.").

196. See generally MARy JANe Bolle, Overview of Labor Enforcement Issues in FREE TRADE AGREEMENTS (2014), archived at http://perma.cc/L5HP-73VK.

197. U.S.-Jordan FTA, supra note 65, art. 6.

198. U.S.-Jordan FTA, supra note 65, art. 6.

199. U.S.-Jordan FTA, supra note 65, art. 6. 
measure[s]." ${ }^{200}$ The decision to proceed with an investigation, consultation, or arbitration; assess a penalty; or order the imposition of sanctions is made by the Agreement's state parties. ${ }^{201}$ Under the Agreement, state parties can submit allegations of labor rights violations either (i) in ministerial consultations leading to non-binding recommendations, ${ }^{202}$ or (ii) applying dispute settlement procedures ${ }^{203}$ which may ultimately result in the imposition of trade sanctions, such as placing or raising quotas and tariffs. $^{204}$ The role of non-governmental parties is confined to the presentation of their views during governmental consultations on the Agreement and the submission of amicus curiae briefs to "dispute settlement panels" convened by the parties to address allegations of noncompliance. ${ }^{205}$ Article 6(4)(b) of the Agreement states:

The Parties recognize that each Party retains the right to exercise discretion with respect to investigatory, prosecutorial, regulatory, and compliance matters and to make decisions regarding the allocation of resources to enforcement with respect to other labor matters determined to have higher priorities. Accordingly, the Parties understand that a Party is in compliance with subparagraph (a) where a course of action or inaction reflects a reasonable exercise of such discretion, or results from a bona fide decision regarding the allocation of resources. ${ }^{206}$

This subparagraph asserts the right of each state party to make decisions as such party may find appropriate in its discretion, concerning, inter alia, the adoption of procedures to maintain the internationally accepted standards. In response to the above-referenced report, the Jordanian Ministry of Labor took emergency administrative measures and put into place a strategic plan to ensure the enforcement of the labor laws and regulation in the Qualified Industrial Zones (QIZs) in Jordan. ${ }^{207}$

200. Agreement Between the United States of America and The Hashemite Kingdom of Jordan on the Establishment of a Free Trade Area, U,S.-Jordan, Oct. 24, 2000 [hereinafter U.S.-Jordan Agreement], archived at http://perma.cc/7U7M-4QR8. The JUSFTA establishes a Joint Committee to supervise the proper implementation of the agreement and to review the trade relationship between the parties. $I d$. art. 15 .

201. Id.

202. See id. art. 16 .

203. See id. art. 17.

204. Id.

205. Id.

206. Id. art. 6(4)(b).

207. Qualifying Industrial Zone, Int'l Trade Admin., http://web.ita.doc.gov/tacgi/fta.nsf/7a9d3143265673ee85257a0700667a6f/196ed79f4f79ac0 085257a070066961d (Aug. 29, 2014, archived at http://perma.cc/3CAM-NJKC). The QIZ 


\section{Rules of Origin}

The ROOs contained in the Jordan-U.S. FTA, as set out in Annex 2.2, have three origin criteria. ${ }^{208}$ First, is a wholly obtained/substantial transformation requirement, which means that goods imported to either Party must be made entirely in one of the FTA countries, or, if any thirdcountry materials are used, those materials must be "substantially transformed" into Jordan-U.S. origin products as a result of a manufacturing or processing operation. ${ }^{209}$ For textile and apparel products, the FTA has a special set of "substantial transformation" rules. ${ }^{210}$ Second, is the 35 percent domestic content requirement, which indicates that 35 percent of the customs value of the imported product must be attributable to Jordanian or US-origin materials and/or to direct costs of processing carried out in the FTA partner. ${ }^{211}$ However, the cost or value of either Jordanianorigin materials or US-origin materials incorporated in the imported product can be counted in the other country, but only up to 15 percent of the customs value of the good. ${ }^{212}$ And third, is the direct transport requirement, which is intended to ensure that qualifying goods are not mixed with nonqualifying goods while en route to Jordan or the United States. ${ }^{213}$

Compared to the European Union approach, the origin criteria for gaining preferential treatment under the Jordan-US FTA are straightforward. While the United States has embraced, adopted, or utilized

scheme is a special free trade zone established pursuant to Section 9 of the United StatesIsrael Free Trade Area implementation Act of 1985, Proclamation No. 6955 of the President of the United States of America and approved by the US Congress. Id. The first QIZ in Jordan was established in 1996 as a method to support the Middles East peace process through strengthen economic ties between Jordan and Israel and as such allows for tariff and quota free imports into the US market of goods. $I d$. To qualify, goods produced in these zones must contain a small portion of Israeli input set at 8 percent and Jordanian input of at least 11.7 percent. $I d$. In addition, a minimum 35 percent value added to the finished product. Id. The scheme has contributed significantly increasing Jordan's exports to the US primarily however in apparel goods with mainly Asia investors. Id. The QIZs offered a window of opportunity, the utility and sustainability of which is in question given the elimination since 2010 of tariffs under the Jordan-US FTA tariff dismantlement arrangement, the continued challenges facing the Middle East peace process, notwithstanding other factors such as the termination in 2005 of the WTO Agreement on Textiles and Clothing which had first encourage footloose investments into the QIZs. Id.

208. Brian J. O'Shea \& Sheri Rosenow, U.S.-JORDAN Free Trade AgreEment: Rules of Origin Manual (2001).

209. Id.; see also U.S.-Jordan Free Trade Agreement, ExPORT.GOV, http://export.gov/FTA/jordan/eg_main_017718.asp (last updated May 12, 2008, archived at http://perma.cc/7XU2-SQZ5).

210. Office of the U.S. Trade Representative, Exec. Office of President, Jordan Free Trade Agreement, U.S.-Jordan, Annex 2.2: Rules of Origin, 19 1, 3-4, Oct. 24, 2000, archived at http://perma.cc/Z2XH-PRXN.

211. Id. 95 .

212. See U.S.-Jordan Free Trade Agreement, supra note 209.

213. OfFice of the U.S. TRAde RePresentative, supra note $210, \boldsymbol{\rrbracket} 8$. 
these ROOs in other FTAs, it does not adopt a unification approach in its use of preferential ROOs. ${ }^{214}$ These ROOs are special and may be explained by political and developmental considerations that the US has for Jordan. Moreover, these ROOs are substantially compatible with the application of the rules on the overall US economy. ${ }^{215}$

Finally, it is to be noted that these simple ROOs are also used under the Agreement of Trading and Economic Cooperation between Jordan and Israel, signed in October 1995. ${ }^{216}$ The Agreement aims at encouraging economic and commercial cooperation between the two countries and includes the reduction of customs tariffs on products of both countries. ${ }^{217}$ In 2005 the Agreement was upgraded by including the Pan-Euro-Med ROOs, which allow for diagonal cumulation of origin, making this Agreement - to the knowledge of the authors - the only agreement to have two separate and co-existing systems of ROOs, leaving it to a trader's discretion to selectively use the set of ROOs that best suits its export and import requirements. $^{218}$

\section{Intellectual Property}

A central feature of the Jordan-US FTA is the WTO TRIPS-plus intellectual property rules. ${ }^{219}$ Data exclusivity was a requirement of Jordan's accession to the WTO and was reflected in the Jordanian Trade

214. See, e.g., ROOs in the Bahrain Free Trade Agreement (Office of THE U.S. TRAdE Representative, Exec. Office of President, Bahrain Free Trade Agreement, U.S.-Bahr, Sept. 14, 2004, archived at http://perma.cc/3TJX-6Z7D); see also Morocco Free Trade Agreement (Office of the U.S. Trade Representative, Exec. Office of President, Morocco Free Trade Agreement, U.S.-Morocco, June 15, 2004); Oman Free Trade Agreement (Office of the U.S. Trade Representative, Exec. Office of President, Oman Free Trade Agreement, U.S.-Oman, Jan. 19, 2006, archived at http://perma.cc/MX9D-82CJ). All contain similar origin rules.

215. See Wolfgang W. Lierer, Rules of the Origin under the Caribbean Basin Initiative and ACP-EEC LOME IV Convention and Their Compatibility with the GATT Uruguay Round Agreement on Rules of Origin, 16 U. PA. J. INT'L. BuS. L. 483 (1995), archived at http://perma.cc/3UNA-NKT2. This regime of the ROO is being used by the US Customs Service to administer its various trade preference arrangements such as the GSP scheme, the Caribbean Basin Initiative, and the Qualified Industrial Zone (QIZ) program. See ECON. \& Commerce Bureau, The Embassy of Jordan, Your Guide to QIZ, archived at http://perma.cc/M2RD-UU25.

216. Agreement of Trading and Economic Cooperation Between the HKJ and the Government of the State of Israel (SI), Isr.-Jordan, Oct. 25, 1995, The World Bank Group [WBG], archived at http://perma.cc/4QZQ-BP6A.

217. Id.

218. $I d$.

219. See generally Memorandum of Understanding on Issues Related to the Protection of Intellectual Property Rights under the Agreement Between the United States and Jordan on The Establishment of Free Trade Area (2000). 
Secrets and Unfair Competition Law, ${ }^{220}$ which introduced a five-year data exclusivity period that commences on the medicine's date of registration in Jordan. ${ }^{221}$ Under article 22 of the Jordan-US FTA, this period was further extended an additional three years for new uses of already known chemical entities. $^{222}$ According to several studies, these intellectual property obligations under the Jordan-US FTA have created obstacles to accessing new technologies in Jordan. ${ }^{223}$ Given this result, the question is why Jordan has agreed to tie itself up in such harsh obligations. A likely explanation is that Jordan had both zero negotiating power with the US and lacked sufficient expertise in free trade dynamics at the time the Agreement was negotiated.

\section{The Substantive Clause}

Another intriguing legal feature is the "substantive clause" found in article 10 of the Jordan-US FTA, which provides that safeguards may be taken when increased quantities of imports are a substantial cause of serious injury or present a threat of serious injury to domestic industries. ${ }^{224} \mathrm{~A}$ substantial cause is defined as "important and not less than any other cause." 225 This is not different from the standard contained in the WTO Safeguards Agreement, which permits the use of safeguard measures when increased imports cause or threaten to cause serious injury to the domestic industry. ${ }^{226}$

\section{G. Jordan-Singapore FTA}

The Jordan-Singapore FTA was concluded in May 2004 and came into force in August 2005. ${ }^{227}$ The FTA eliminates tariffs on all goods (excluding 2.4 percent of Jordan tariff lines) within ten years from entry

220. Trade Secrets and Unfair Competition Law, Official Gazette No. 4423 (Law No. 15/2000) (Jordan).

221. See id.

222. U.S.-Jordan FTA, supra note 65, art. 22.

223. See, e.g., Oxfam InT'L, All Costs, No Benefits: How TRIPS-Plus Intellectual PROPERTY Rules IN THE US-JORdAN FTA AFFECT ACCESS TO MEDICINES (2007), archived at http://perma.cc/6UR5-64BY. This study shows that the prices of medical products have skyrockted in Jordan since the FTA, partly as a result of TRIPS-plus rules. See id. at 2. It concludes that the FTA measures have not benefited from direct investment or research and development. $I d$.

224. U.S.-Jordan FTA, supra note 65, art. 10.

225. Id.

226. Id.

227. Agreement Between the Government of the Hashemite Kingdom of Jordan and the Government of the Republic of Singapore on the Establishment of a Free Trade Area, Jordan-Sing., May 16, 2004, archived at http://perma.cc/TK4C-RQAE [hereinafter JordanSingapre FTA]. 
into force at an asymmetrical manner over a five-to-ten-year period. ${ }^{228}$ The Agreement also allows for the creation of new goods export opportunities to other markets by applying a diagonal cumulation of origin with countries that have an FTA with both Jordan and Singapore, namely the European Free Trade Agreement and the United States. ${ }^{29}$

The fourth chapter deals with trade-in Services. It ensures that service suppliers in Jordan and Singapore are guaranteed access to each other's markets. ${ }^{230}$

Some examples of service-related sectors benefitting from the Agreement are computer and related services, educational services, research and development services, and services incidental to manufacturing and convention services. $^{231}$

The Agreement provides for further liberalization in a number of services sectors by both parties exceeding current liberalization pace within the scope of the WTO. ${ }^{232}$ With the aim of attracting joint investments, Jordan offers extra liberalization for Singaporean services providers for research and development in fields of natural, social, and human sciences; in advertising services; and in services incidental to manufacturing, convention services, and water treatment services. ${ }^{233}$ Conversely, Singapore also offers extra liberalization for Jordanian services providers in a number of sectors. The most important of these are computer and related services and research and development services in the fields of natural, social, and human sciences; advertising services; management consultancy services; real estate services; renting and leasing without operators; technical testing and analysis; and building cleaning, photography, and packaging services. ${ }^{234}$ "The [A]greement also addresses cooperation in financial and transport services of all forms (sea, road, and air) between the two countries. $" 235$

228. See id. Annex II, archived at http://perma.cc/H87G-VHXP ("2. Aside from products listed in paragraphs 3, 4, 5, 6 and 7 of this Annex, customs duties and any other charges having equivalent effect on products originating in Singapore and exported directly into Jordan shall remain at base rates for the first five years of implementation. Thereafter, beginning January 1 of year six from date of entry into force of the Agreement, the rates of duty shall be progressively abolished in five equal annual stages over five consecutive years. Such goods shall be duty-free effective January 1 of year ten.”)

229. See generally id:; Committee on Regional Trade Agreements, Report by the Secretariat, Revision: FACTUAL PRESENTATION: Free Trade Agreement Between JoRDAN AND SingAPORE (GOODS AND SERVICES), WT/REG215/2/Rev.1, 9, tbl.III.1A (2008).

230. Id. ch. 4.

231. See generally Greater Arab Free Trade Area (GAFTA), supra note 83.

232. See Jordan-Singapre FTA, supra note 227, art. 4.

233. AnNex II to the AgreEment (Jordan's Schedule of Specific Commitments), archived at http://perma.cc/RP5V-T5PD.

234. Id.

235. Id. 
Chapter 5 of the FTA with Singapore also contains obligations relating to electronic commerce in which each party agrees to forego deviating from its existing practices of not imposing customs duties on electronic transmissions, imposing unnecessary barriers on electronic transmissions, including digitized products, and impeding the supply through electronic means of services subject to a commitment under Chapter $4 .^{236}$ Jordan and Singapore have a Bilateral Investment Treaty that came into force on August 22, 2005. ${ }^{237}$

\section{H. Jordan-Canada FTA}

Jordan and Canada signed a Free Trade Agreement in June 2009 that came into force in October 2012, together with a Labour Cooperation and Environment Agreement that came into force at the same time. ${ }^{238}$ The FTA allows Jordan to export goods, tax-free, to Canada, and it allows Canadian firms to export to Jordan, thereby increasing competition. ${ }^{239}$ The ROOs set out in this Agreement are based on altering harmonized system codes that take into account the comparative advantage and competitive capabilities of local industries, ${ }^{240}$ which is an easy method when compared with other preferential ROOs.

The Agreement establishes a free trade area in goods only, and as such does not cover services liberalization. ${ }^{241}$ In Chapter 3 on electronic commerce, parties agree not to apply customs duties to products delivered electronically. ${ }^{242}$ On June 28, 2009, Jordan and Canada also signed the Foreign Investment Protection and Promotion Agreement (FIPA), ${ }^{243}$ which came into force on December 14, 2009. ${ }^{244}$

236. See Jordan-Singapre FTA, supra note 227, ch. 5.

237. Bilateral Investment Treaty between the Government of the Hashemite Kingdom of Jordan and the Government of the Republic of Singapore, May 16, 2004, archived at http://perma.cc/Q4X-NRK7.

238. Foreign Affairs and International Trade Canada, FAST FACTS: FREE TRADE With JORDAN (July 18, 2011), http://www.international.gc.ca, archived at http://perma.cc/KRR7NHZB. See also Anne Amos-Stewart et al., Chapter 4: All Talk and No Action: Access to Canadian Markets under the General Agreement on Trade in Services, 11 Asper Rev. Int'1 Bus. \& Trade L. 91 (asserting that Jordan- Canada deals with goods only).

239. Id.

240. Ministry OF IndUSTRY \& TRADE, www.mit.gov.jo (last visited Dec. 28, 2012, archived at http://perma.cc/ET4A-9MQB). The Jordan-Canada FTA has not been notified to the WTO to date.

241. See Jordan-Singapre FTA, supra note 227, art. 2.

242. Jordan-Singapre FTA, supra note 227, ch. 3.

243. Agreement Between Canada and the Hashemite Kingdom of Jordan for the Promotion and Protection of Investments, Can.-Jordan, June 28, 2009, archived at http://perma.cc/LZ55-7NG5.

244. Id. 
The FIPA is a common feature in Canada's free trade deals. ${ }^{245}$ In the Jordanian case, specifically, the FIPA was strangely imbalanced and biased to offer Canadian investors in Jordan more rights and privileges than domestic investors, including the Jordanian government. ${ }^{246}$ For instance, the Canada-Jordan FIPA's dispute settlement mechanism allows Canadian investors to forgo the domestic judicial system (whether courts or arbitration) and refer to international arbitration if there has been any alleged breach of treaty protection. ${ }^{247}$ Of course, international arbitrators might show bias in favor of international investors and influential states such as Canada. ${ }^{248}$ This has particular importance especially if the dispute concerns public policy matters such as public order, health, and environment. Furthermore, the FIPA has clauses that protect against indirect expropriation. ${ }^{249}$ In other words, if a domestic law or a regulation undermines the value of a foreign investment, compensation could be ruled for. In such case, and because a country generally cannot be forced to amend laws, an international arbitration panel may impose exaggerated compensation. ${ }^{250}$

This is probably a standard Canadian FIPA that applies to all of its preferential partners. Likewise, Jordan's FIPA with Canada does not on its face favor Canada; rather, it is a de facto imbalance in favor of the developed and more capable partner in the equation. ${ }^{251}$ However, Jordan could have insisted on keeping local adjudication an option and mitigated the language that provides for compensation on the so-called "regulatory expropriation." 252

245. Agreement Between Canada and [ ] for the Promotion and Protection of Investments, art. 10 (2004), archived at http://perma.cc/QL2J-JJLY [hereinafter 2004 Canada Model BIT].

246. Full text archived at http://perma.cc/KR27-VPJZ.

247. See Canada-Jordan Free Trade Agreement, ForeIgn AfFAirs, TrADE, AND DEVELOPMENT CANADA, http://www.international.gc.ca/trade-agreements-accordscommerciaux/agr-acc/jordan-jordanie/chapter14-chapitre14.aspx?lang=eng (last updated Mar. 16, 2012, archived at http://perma.cc/4BR-U4VT).

248. See Susan Franck, The ICSID Effect? Considering Potential Variations in Arbitration Awards, 51 Va. J. Int'l. L. 977 (2011) (stating that bias is possible in favor of developed countries in international arbitration); see also Is Investment Treaty Arbitration Biased Against Developing Countries?, INT'L. L. \& ECON. POL'Y. Blog, http://worldtradelaw.typepad.com/ielpblog/2011/06/is-investment-treaty-arbitration-biasedagainst-developing-countries.html (last visited Aug. 29, 2014, archived at http://perma.cc/ET4F-SUFT).

249. Agreement Between Canada and the Hashemite Kingdom of Jordan for the Promotion and Protection of Investments, supra note 243.

250. Agreement Between Canada and the Hashemite Kingdom of Jordan for the Promotion and Protection of Investments, supra note 243.

251. See Agreement Between Canada and the Hashemite Kingdom of Jordan for the Promotion and Protection of Investments, supra note 243, art. 13.

252. For information on the notion of regulatory expropriation, see BILATERAL 


\section{PART V. LESSONS LEARNED ON JORDAN'S REGIONALIZATION}

Developing countries face challenges arising from the increasing number of RTAs. ${ }^{253}$ This is particularly true for a small country like Jordan, strategically situated in an unstable region of the world, in which political consideration drives much of Jordan's national socioeconomic measures and its international relations. This increased number of RTAs possibly will disturb Jordan's decision-making process with respect to its options in multilateral, regional, and preferential trade. Nevertheless, the basic economic premise of comparative advantage remains valid. As evidenced by Jordan's case, trade openness alone does not and cannot generate economic growth. However, the linkages between a country's external trade policy and its international obligations, namely how they properly reflect the national economic framework (legal and otherwise) and whether they are supported by national economic development projects, are key to benefitting from the possibilities that RTAs offer.

Jordan's choice of trade partners clearly shows a variety in both the levels of development (Jordan has both south-south and north-south RTAs) and geographic proximity (ranging from the Americas to Asia). ${ }^{254}$ The reasons that might explain this mixed selection of Jordan's RTA partners are to a large extent rooted in political considerations. The economic merits of these RTAs (current or planned) for a small and troubled economy such as Jordan's are essentially based on the traditional premise that such agreements provide trade advantages that allow for improved competitiveness and better insertion into the international economy. ${ }^{255}$

An examination of the nineteen-page National Foreign Trade Strategy and its annexes reveals an overly simple text with limited analyses, a list of actions and/or goals more resembling a policy note, and provisions that can ultimately be described as containing procedural rather than targeted measures intended to stimulate growth. ${ }^{256}$ With respect to Jordan's regionalization, the strategy reaffirms the current course, and clearly provides for the "entering into bilateral trade agreements" (objective 4/1) and "the active involvement in the multilateral negotiations in the framework of the WTO, the Arab League and the Organization of the

INVESTMENT TREATIES: A CANADIAN PRIMER 2, archived at http://perma.cc/KQ8C-9B8Y.

253. See generally Jim Rollo, The Challenge of Negotiating RTA's for Developing Countries: What COUld THE WTO Do TO Help? (2007), archived at http://perma.cc/DCC3-FX63.

254. See generally WORLD BANK, WORLD BANK LIST OF ECONOMIES (July 2012), archived at http://perma.cc/7ZKD-XUUL.

255. See Jordan's Foreign Trade Policy, Ministry of Industry \& Trade, http://www.mit.gov.jo/tabid/475/Jordan\%20Foreign\%20Trade\%20Policy.aspx (last visited Dec. 28, 2012, archived at http://perma.cc/Y4BZ-5L3Y).

256. Trade Policy Review Body Report, Report by Jordan, WT/TPR/G/206 (Oct. 6, 2008), archived at $\mathrm{http}: / /$ perma.cc/M49L-BVBR. 
Islamic Conference" (objective 4/2). ${ }^{257}$

The tables below provide a statistical snapshot of Jordan's trade balance in goods, services, and overall trade balance.

\begin{tabular}{|c|c|c|}
\hline \multicolumn{3}{|c|}{$\begin{array}{l}\text { Jordan's goods imports and exports under its RTA for } 2011 \text { (in million } \\
\text { Jordanian Dinars) }\end{array}$} \\
\hline Agreement & Exports & Imports \\
\hline GAFTA & $2,262.7$ & $4,849.1$ \\
\hline Jordan-EU AA & 223.5 & $2,675.9$ \\
\hline Jordan-US FTA & 733.8 & 765.1 \\
\hline Jordan-EFTA & 13.8 & 123.4 \\
\hline Agadir & 105.6 & 556.7 \\
\hline Jordan-Singapore & 4.6 & 17.9 \\
\hline Jordan-Turkey & 62.6 & 389.8 \\
\hline Jordan-Canada & 9.1 & $60.7^{258}$ \\
\hline
\end{tabular}

\begin{tabular}{|c|c|c|c|c|c|}
\hline \multicolumn{5}{|c|}{ Balance of Payments (Standard Presentation) } & \multirow[b]{2}{*}{2007} \\
\hline Year & 2011 & 2010 & 2009 & 2008 & \\
\hline $\begin{array}{l}\text { Services } \\
\text { Account }\end{array}$ & 470.7 & 838.5 & 523.0 & 249.6 & 22.0 \\
\hline Travel (Net)** & $1,305.8$ & $1,429.5$ & $1,311.4$ & $1,376.2$ & $1,012.5$ \\
\hline Receipts & $2,129.8$ & $2,545.3$ & $2,066.8$ & $2,088.5$ & $1,638.3$ \\
\hline Payments & 824.0 & $1,115.8$ & 755.4 & 712.3 & 625.8 \\
\hline $\begin{array}{l}\text { Transportation } \\
(\mathrm{Net})\end{array}$ & -931.6 & -714.9 & -817.5 & -996.6 & -817.7 \\
\hline Receipts & 843.6 & 794.2 & 564.5 & 593.1 & 468.4 \\
\hline Payments, o/w: & $1,775.2$ & $1,509.1$ & $1,378.6$ & $1,589.7$ & $1,286.1$ \\
\hline Freight & $1,208.0$ & 992.5 & 907.7 & $1,083.8$ & 873.6 \\
\hline $\begin{array}{l}\text { Government } \\
\text { Services (Net) }\end{array}$ & 201.6 & 193.5 & 150.7 & -53.6 & -34.7 \\
\hline Receipts & 285.9 & 269.4 & 253.9 & 88.6 & 79.6 \\
\hline
\end{tabular}

257. National Strategy for Foreign Trade, supra note 79, at 16 (the text is translated from the Arabic as it appears in the Strategy, in which a differentiation is made between multilateral negotiations in the meaning of the WTO on the one hand, and, on the other hand, negotiations in the context of multilateral negotiations within the Arab League or the Organization of the Islamic Conference); see also Jordan's Foreign Trade Policy, MINISTRY of Industry AND TRADE: THE HASHEMite Kingdom OF Jordan, http://www.mit.gov.jo/tabid/475/Jordan\%20Foreign\%20Trade\%20Policy.aspx (last visited Sep. 7, 2014, archived at http://perma.cc/Q2N4-QWS8);

258. External Trade by Economic Function of Commodity Groups, DePARTMENT of STATISTICS, http://www.dos.gov.jo/dos_home_e/main/index.htm (last visited Sep. 7, 2014). 


\begin{tabular}{|l|l|l|l|l|l|}
\hline Payments & 84.3 & 75.9 & 103.2 & 142.2 & 114.3 \\
\hline $\begin{array}{l}\text { Other } \\
\text { Services (Net) }\end{array}$ & -105.1 & -69.6 & -121.6 & -76.4 & -138.1 \\
\hline Receipts & 389.0 & 367.1 & 348.3 & 408.0 & 329.5 \\
\hline Payments & 494.1 & 436.7 & 469.9 & 484.4 & 467.6 \\
\hline
\end{tabular}

\begin{tabular}{|l|c|c|}
\hline \multicolumn{2}{|c|}{ Balance of Payments (Standard Presentation) } \\
\hline Year & Month & $\begin{array}{c}\text { Trade Balance } \\
\text { ( Net ) (Million JD) }\end{array}$ \\
\hline 2005 & 12 & -3556.3 \\
\hline 2006 & 12 & -3584.7 \\
\hline 2007 & 12 & -4574.2 \\
\hline 2008 & 12 & -5084.4 \\
\hline 2009 & 12 & -4448.8 \\
\hline 2010 & 12 & -4823.8 \\
\hline 2011 & 12 & $-6261.7^{259}$ \\
\hline
\end{tabular}

The tables above suggest that Jordan's free trade and, more specifically, regional trade were not on the whole a success story as Jordan's trade deficit is worsening. In other words, Jordan's regional and preferential trade arrangements did not fully and significantly improve Jordanian economic (and perhaps political) welfare. Arab inter-regional trade remains weak in areas where it is argued that many of the economies have competing sectors rather than complementary ones. ${ }^{260}$ In the context of the Euro-Med Free Trade Area, goods trade between the EU and Jordan continues hub-and-spoke rather than regionally, even with cumulation offered by the Pan-Euro-Med preferential rules of origin found in the Agadir Agreement, as well as in Jordan's FTA with EFTA and Turkey. Additionally, Turkey, with its growing and dynamic economy, poses a real threat on the national industries' ability to meet local demand at competitive quality and pricing. ${ }^{261}$ Except for trade with the US, which is largely based on a short-term tariff advantage textile sector, the overall equilibrium of regional trade for Jordan is unsustainable in the long run.

The economic implications of induced trade liberalization on

259. CENTRAL BANK OF JORDAN, http://statisticaldb.cbj.gov.jo/index?lang=en (last visited Sep. 1, 2014, archived at http://perma.cc/JT6W-4EZJ).

260. Arab NGO Network for Development, The Arab Region and Trade LIBERALIZATION POLICIES 16, archived at http://perma.cc/KNM5-AWS4.

261. See Turkey GDP Growth Rate, Trading Economics, http://www.tradingeconomics.com/turkey/gdp-growth (last visited Sep. 1, 2014, archived at http://perma.cc/4JLF-4FWF). 
aggregate economic performance in Jordan, as well as its effects on welfare and income distribution of heterogeneous households, are continuously being investigated. ${ }^{262}$ Generally, trade liberalization has contributed to decreasing prices of imported goods. ${ }^{263}$ This causes the prices of investment and consumption to decrease since investment goods are composites of foreign and domestically produced goods. ${ }^{264}$ Incentives for investment increased, which in turn spurred faster capital accumulation, i.e. a higher steady state value of aggregate capital. ${ }^{265}$ However, while the Jordanian government transfers have decreased due to foregone import duties, the loss in government revenue due to this import duty reduction is partially offset in the long run by the expansion in the tax base and the development of a more sophisticated sales tax structure (e.g., GST on mobile telecommunication services is currently 18 percent). ${ }^{266}$ The fear exists, however, that a widening income gap follows from the resulting higher capital income. ${ }^{267}$ This means that it is not certain that trade liberalization benefits all segments of society; rather, it could result in the magnification of the wealth of the few at the expense of the majority. ${ }^{268}$

The composition of the Jordanian GDP stands at 4.5 percent agriculture, 30.8 percent manufacturing, and 64.7 percent services, in which 98 percent of all private firms in Jordan are micro-and small enterprises that employ only 1 to 4 and 5 to 19 workers, respectively. ${ }^{269}$ The services sector holds the biggest potential, and Jordan already possesses many of the

262. Omar Feraboli \& Timo Trimborn, Trade Liberalization AND Income DiSTRIBUTION: A CGE MODEL FOR JORDAN, archived at http://perma.cc/JKA8-4RZW. This is done by introducing heterogeneous households into a standard neoclassical dynamic computable general equilibrium model (CGE). Therefore, individual households' tax rate, wage rate, initial endowment of assets, transfers from government and abroad, as well as individual preferences, are calibrated by data from a household survey.

263. See Diana Tussie \& Carlos Aggio, Economic and Social Impacts of Trade LiBERALIZATION 89, archived at http://perma.cc/JD9-NNC6 (discussing how trade liberalization makes prices go down).

264. Id.

265. Id. at 95 .

266. See The World Bank, Paying Taxes in Jordan, Doing Business: MEasuring BUSINESS REGULATIONS, http://www.doingbusiness.org/data/exploreeconomies/jordan/ paying-taxes/ (last visited Sep. 1, 2014, archived at http://perma.cc/C8YT-PPJ7).

267. For Jordan's income economic indicators see Jordan - Income Distribution, Index Mundi, http://www.indexmundi.com/facts/jordan/income-distribution (last visited Sep. 1, 2014, archived at http://perma.cc/4LZ7-M72G); Economic Indicators - Jordan, EarthTrends,

http://www.unep.org/dewa/WestAsia/Data/Knowledge_Bases/Jordan/WRI/Eco_cou_400.pdf (last visited Sep. 1, 2014, archived at http://perma.cc/XRZ3-SC9L).

268. See Donald R. Davis, Trade Liberalization and Income Distribution (Nat'l Bureau of Econ. Research, Working Paper No. 5693, 1996), archived at http://perma.cc/V5UMANES (detailing the possible adverse effects of trade liberalization).

269. See DeP'T OF StATISTICS - JoRdAn, www.dos.gov.jo (last visited Oct. 20, 2013, archived at $\mathrm{http}: / /$ perma.cc/S3VL-G3T5). 
capabilities (such as a young, educated workforce and technological openness) needed to move forward. ${ }^{270}$ While Jordan's industrial policy continues to develop, largely pushed by international and other donors, its government continues to suffer, generally due to limited financial resources, high nepotism, and deep corruption. ${ }^{271}$ Additionally, other non-economic but equally vital elements such as limited capacities and expertise, shortage or lack of updated or accurate data, as well as short-term private interests weigh heavily on the overall economic planning process. ${ }^{272}$

The idea of international trade as advocated by Ricardo and Viner was predicated on the comparative advantage theory. ${ }^{273}$ Both scholars found that free good exchange offers reciprocal economic benefits. ${ }^{274}$ When each party in trade specializes in producing the product at which it excels, each party will obtain the other's at a lower cost while still efficiently producing their own. ${ }^{275}$ But to apply this theory correctly, Jordan has to excel by specializing in producing certain goods and services. Jordan also must be mindful of certain clauses under its FTA commitments, such as the investment clause in its agreement with Canada and the intellectual property commitments under its agreement with the US. If Jordan cannot amend burdensome clauses in its FTAs, then remedying actions must take place to rectify the negatives. For instance, if Jordan cannot revisit its agreement with the US with respect to intellectual property clauses, it should allocate more resources and spending on public health and technology to "offset the

270. See World Travel and Tourism Council, Travel and Tourism Economic IMPACT: 2012: JORDAN (2010) (generally showing that export of services offers Jordan an opportunity to increase exports and to reduce its trade balance.).

271. A Snapshot of Corruption in Jordan, Business Anti-Corruption Portal (Feb. 2014), http://www.business-anti-corruption.com/country-profiles/middle-east-northafrica/jordan/snapshot.aspx, archived at http://perma.cc/HRE9-QD7W.

272. WORld BANK, JORDAN ECONOMIC MONITOR, MAINTAINING Stability AND Fostering SHARED Prosperity Amid Regional Turmoll 6 (2013), archived at http://perma.cc/R4NF-R8Z3 (describing the aspects of deterioration in the Jordanian economy).

273. See generally Jacob Viner, Studies in the Theory of International Trade 438 (1960); see also Jacob Viner, The Customs Union Issue, in Trading Blocs, Alternative Approaches to Analyzing Preferential Trade Agreements (Jadish Bhagwati \& Arvind Panagariya, eds., 1999).

105 at.

274. Kirk Kennedy, Deconstructing Protectionism: Assessing the Case for a Protectionist American

Trade Policy, 28 Case W. Res. J. Int'l L. 197, 203 (1996) (explaining Ricardo's Comparative Advantage Theory); but see Robert W. Benson, Free Trade as an Extremist Ideology: The Case of

NAFTA, 17 U. Puget Sound L. Rev. 555, 557 (1994) (implying that Ricardo's theory is flawed).

275. Id. 
impact of TRIPS-plus rules on consumers. ${ }^{276}$ Similarly, if Jordan cannot revisit its agreement with Canada regarding investment treatment, it must take measures to enhance the competitiveness of Jordanian investors, particularly in this phase of Jordan's history which has witnessed unprecedented economic and political transformations, ${ }^{277}$ a nearly impossible mission as the agreement has recently entered into force.

\section{CONCLUSION}

This Article has attempted to shed light on some matters related to Jordan's free trade policy and agreements after more than a decade from the signing of its first FTA with the US. The rationale behind trade liberalization remains the achievement of economic benefit, yet Jordan continues to pursue trade liberalization with a political mentality that does not necessarily coincide with its economic interests. Jordan has even limited its capacity to make use of the trade preferences offered under its FTAs, some of which deprive Jordan of the flexibility awarded to developing countries within the multilateral system (such as the FTA with the United States, which introduced tougher intellectual property protection).

In conclusion, Jordan is seeking regional trade deals without doing its due diligence. It is true that Jordan's liberalization has increased its exports, but it also increased its imports in rapid and significant manners. This has led to a worse "chronic trade deficit." 278 Jordan has too willingly believed in, and depended on, the "Washington Consensus." The due diligence that Jordan should conduct involves a national strategy for trade that encompasses a national export strategy with a proactive action plan. This strategy must make a full use of the privileges given to developing countries. The strategy must outline Jordan's comparative and competitive advantages and evaluate Jordan's FTAs from all angles, both economic and legal. Jordan must invest more in its services capital especially when engaging in regional and preferential trade agreements as Jordan does possess potential in providing services. All in all, Jordan needs to create a new philosophy for trade with a goal of welfare creation, not trade liberalization and random regionalization. This is not a call for

276. Ryan Abbott, Access to Medicines and Intellectual Property in Jordan, BILATERALS.ORG (July 23, 2012).

http://www.bilaterals.org/spip.php?article21839, archived at http://perma.cc/Y8DJ-R2HH.

277. See Musa Hattar, Jordan Fuel Price Hike Protests Turn Violent, MidDLE EAST ONLINE (Nov. 15, 2011), http://www.middle-east-online.com/english/?id=55510, archived at http://perma.cc/WK9B-RMMA (discussing the latest rise in fuel prices and the violence that besieged Jordan).

278. Taleb Awad Warrad, WTO Chairs Programme Annual Conference, The Potential Economic Effects of FTA Between Jordan and Canada (June 21, 2011), https://www.wto.org/english/tratop_e/devel_e/train_e/Jordan.pdf, archived at http://perma.cc/G448-E3CE. 
protectionism. This is a call for a better use of the tools that developing countries have under WTO law to enjoy the benefits of trade liberalization. 